\title{
National Identity and British Foreign Policy
}

\author{
Srdjan Vucetic
}

\section{Paper* prepared for the 2020 Britain and the World Conference, University of Plymouth, 17- 19 June 2020**}

\begin{abstract}
Britain's tenaciously global foreign policy after 1945 was never simply a function of the nation's ruling class acting on the basis of elite obsessions or after some sort of bipartisan consensus. Rather, this policy developed from mainstream, gradually evolving ideas about "us," "them," and "Others" generated within a broader British and, more specifically, English society.

* Introduction of a book ms. (the rest available upon request)

** Due to COVID-19, the conference is now scheduled to take place in 2021
\end{abstract}

Srdjan Vucetic is Associate Professor at the Graduate School of Public and International Affairs, University of Ottawa. He is the author of The Anglosphere: A Genealogy of a Racialized Identity in International Relations (Stanford 2011) and co-editor of Canadian Defence Policy in Theory and Practice (Palgrave 2020). His work has also appeared in journals such as European Journal of International Relations, Foreign Policy Analysis, International Organization and The British Journal of Politics and International Relations. Contact: https://srdjanvucetic.wordpress.com/ 


\section{Introduction}

"At the very point of junction." "At the top table." "Punching above our weight." "Pivotal power." "Significant global power." "Global hub." "Global Britain." "Major global player." "Great global player." "True global player." These are some of the official and officious designations of British foreign policy in the post-Second World War period. Dreamed up by policy-makers and commentators of different eras, party politics, and ideologies to describe and proscribe the ambitions of the United Kingdom (UK) in the world, these phrases also index a long-standing policy "problem": how to pursue a robust global power policy in the face of relative decline, meaning the visible erosion of the state's international position.

But so elusive were the solutions that this became a problem to be managed, not solved, as in an oft-repeated saw: "In the 1950s we in Britain managed decline; in the 1960s we mismanaged decline; and in the 1970s we declined to manage" (Brown 2004). The problem persists into the twenty-first century. "We still struggle to adjust to our reality," declared the Guardian in a hard-hitting 25 January 2010 editorial: “The UK’s World Role: Great Britain's Greatness Fixation," which argued that an exceptionalist desire to be "the leading nation, not just one of them," was bipartisan and thus hard to eradicate. "But this way hubris lies." The warning came at a time when the then Conservative-led government embarked on "austerity" supposedly an effort to "prune" state spending in response to the global financial crisis of 2008, but in fact yet another iteration of "neoliberalization." Then, in the midst of this and many other destabilizing events and processes around the world, came "Brexit," the UK's much-bungled, and still ongoing, exit from the European Union (EU). A new round of sneers and taunts came in. "There are two kinds of European nations," said one continental politician in 2017: "There are 
small nations and there are countries that have not yet realized they are small nations." Brexit, said another, is "the real end of the British Empire."

Although crude and rude, such statements contain an element of truth. Yes, the UK remains the fifth or sixth largest economy in the world, a top trading nation, a top cultural power, and a top military power - one fielding both nuclear weapons and a functional blue-water navy with a permanent seat on the United Nations (UN) Security Council. Yet, rather than reasserting its "confident role" as a "global power," as per the Conservative "Brexiter" lexicon circa 2018, the UK is also facing major constraints on economic growth, government borrowing, diplomatic influence, and national unity. The ongoing global pandemic of the disease caused by the novel coronavirus COVID-19 exacerbates this predicament by orders of magnitude, not least because of the incompetent, even callous initial response of the government of Boris Johnson.

Britain's global power role fixation is a puzzle that has fascinated not only generations of scholars, historians above all (Darwin 2009, 13-17), but also political geographers (Taylor 2016 [1990], xi) and sociologists (Go 2011, 21-2). In this book, I approach it from the standpoint of international relations (IR) theory (McCourt 2014a, 3-6; see also Hill 2018; Freedman and Clarke 1991). I begin my theorizing with the basic constructivist notion that national identity informs and shapes the matrices of legitimate foreign policy. I then proceed to interpret a selection of events that are at the centre of both British policies and international politics in the post-Second World War period. Britain's bid to “be everywhere, do everything," I argue, was never simply a function of the ruling elite's obsessions; rather, it emerged from British and (mostly) English society as a whole and, more specifically, from the deep-rooted, routine, and (mostly) unreflective discourses through which "Britain" became a presence in the everyday lives of its citizens, elites and masses alike. To again put it rudely and crudely: whatever the 
circumstances of the kingdom's relative decline, "the British" configured themselves as a special edition of humankind. And therein lies a key reason that leaders advocating for foreign policy retrenchment could only question the mechanisms of global power projection, not global power projection as such.

\section{The Third Superpower}

In 1943, when American IR scholar William T.R. Fox coined the term "superpower" to describe states able to wield significant and exceptionally mobile military power independently from other states, he emphatically had the UK in mind as well. This, he later explained, was an error, albeit one that many of his peers committed that decade (Fox 1980, 417, 420).

This should not be all that surprising. Emerging victorious from the most widespread and deadliest conflict in history, Britain held to an empire so vast and so complex that John Darwin (1991) rightly calls it "a British system of world power." Even after India and four more Asian colonies gained independence between 1947 and 1948 - "an unavoidable and unique development that demanded compensation elsewhere" (Harrison 2009, 7-8) - the British Empire was still the world's largest and easily the preeminent power in Africa, the Middle East, the Mediterranean, and, thanks to the giant British Army of the Rhine, in Western Europe. Countless places in the Asia-Pacific and the Caribbean flew the Union Jack, too; some of them, like Kure in Japan, for the very first time (Perkins 2003).

Thanks to the multifaceted nature of imperial power, "decolonization" in fact enabled redeployment and redistribution of metropolitan influence - a phenomenon variously dubbed "neo-colonization," "empire by other means," "second colonial occupation," or "the Third 
British Empire.”3 As detailed by Sarah Stockwell (2018), for instance, assorted "development" programs provided thousands of British officials with well-paying jobs overseas well into the post-empire era.

Britain's high international status was recognized not only by the "old" and "new" Commonwealths - the old refers to the ex-colonies of white settlement where the British Crown and British power enjoyed most respect - but also by the other fifty or so states and empires, including, crucially, the two superpowers. An eloquent testimony to this fact is the Potsdam Conference of 1945, where UK prime ministers Winston Churchill and Clement Attlee sat at the "Big Three" table with Soviet leader Joseph Stalin and United States (US) president Harry Truman. The same goes for Soviet calls, in the winter of 1946-47, for an Anglo-Soviet condominium that would divide Europe into two. ${ }^{4}$ Others admired Britain precisely for rejecting such overtures.

Ample recognition also came in the international institutional context. British diplomats made an outsized contribution to the establishment of the Bretton Woods system and the United Nations. They would have also helped build the European Coal and Steel Community had the UK government chosen to join it like it joined the Brussels Pact and the Organization for European Economic Co-operation in 1948 or the Council of Europe and the North Atlantic Treaty Organization (NATO) in 1949 (Barker 1983, 112-20; Adamthwaite 1985; Blackwell 1993).

Next, the UK controlled almost a third of Western Europe's industrial output and almost a quarter of the world's manufacturing exports. British leadership in science and technology was even more formidable, as David Edgerton (2005, 2018b) has shown: just look at per-capita 
numbers of scientists, engineers, and Nobel prizes or at the UK's accomplishments in jet aviation - the world's first jet-liner, for example - or in nuclear research and development, including the swift progress to the first atomic bomb test in 1952.

Last but not least, the world's financial arrangements were mostly made in the city of London (Strange 1971; Schenk 2010; Cain and Hopkins 2016; Fichtner 2017; Green 2020). Related, nearly half of the world's trade was denominated in pound sterling, which, despite its problems, still counted as a credible "master currency" and therefore as a "prestige symbol of the first order" (Dobson 1995, 164; see also Shonfield 1958, 103-4). Put all these facts together, and you, too, might see the Britain of the late 1940s as one of the Big Three, a nation that was, "as never before, trying to act as a superpower" (Reynolds 2000, 2).

The key word, of course, is "trying," for that same Britain had larger debts than any other nation in history. Worse, this was only a symptom of a structural weakness that the war and the coming superpower era laid bare: "It was unlikely that a nation with only two percent of the world's population could control over a fifth of its land surface, maintain half of its warships and account for 40 per cent of its trade in manufactured goods for very long" (Reynolds 2000, 33). Once the fabled hegemon of hegemons - in IR theory, hegemony refers to leadership of an international order - the British Empire was now inexorably contracting, however savvy the optics management of the Empire-to-Commonwealth transition at the time.

In materialist, objectivist IR, a great power is said to be in decline when it sheds capabilities, especially economic capabilities, relative to other great powers for at least five consecutive years. From this perspective, a "Brexit" from the top-tier league occurred sometime before the mid-1950s. ${ }^{5}$ In contrast, above all, British "declinologists" tend to view decline as a 
relational and intersubjective reality - a set of interpretations and meanings that actors invent to make sense of the objective world. ${ }^{6}$ Building on the latter ontology, I propose to trace Britain's decline and declinism via discourses of British identity, a.k.a. "Britishness" - structured practices of communication on how "we" understand "us," "them," and "Others." In a treasury memorandum penned for the new Labour government on 13 August 1945, John Maynard Keynes voiced his concerns about the risk of bankruptcy or, as he described it, "a financial Dunkirk." If this came to pass, Britain would have to come home right away: "Abroad it would require a sudden and humiliating withdrawal from our onerous responsibilities with great loss of prestige and an acceptance for the time being of the position of a second-class Power, rather like the present position of France" (Keynes 1945).

Fretting over "loss of prestige" vis-à-vis "them," the US and Soviet superpowers, and "Others," such as France, was indeed commonplace in Whitehall after the war. In the end, Her Majesty's Treasury managed to survive - in large part thanks to a steady influx of US dollars, including those associated with Marshall Plan aid. But so did the kingdom's claim to global power. In 1946-47, Foreign Secretary Ernest Bevin, the Foreign Office, and chiefs of staff famously defeated Attlee's proposals for reducing Britain's commitment-capability gaps (Bew 2016, 421-4). The prime minister was not arguing for a wholescale abandonment of the great power status that his Victorian and Edwardian predecessors had practised so well but, rather, for a withdrawal from the Middle East. Yet his opponents would have none of it, likening the proposed policy to "Munich," "the abdication of our position as a world power" (Darwin 2009, 536), and a transformation of Britain into “another Belgium” (Louis 2006, 23).

Hyperbolic comparisons with Belgium - "a country invented by the English to annoy the French," as an old jibe goes - were not new to identity discourses of Britain's ruling class even 
then. In 1908, then ex-viceroy of India Lord Curzon saw England sinking from the position of "the arbiter" to that of "a sort of glorified Belgium" (Danchev 1998, 164). What is puzzling is that this trope never went out of fashion - not after 1945, not after 1956, not after 1973, not after 1990, not after Brexit. "Not just another Belgium" was in fact akin to a strategy.

\section{Just Another?!}

Let us start with the so-called postwar, a.k.a. Bevinite, consensus. ${ }^{7}$ Ernest Bevin certainly deserves to have his name immortalized in this way for he ensured that Labour stayed the course on foreign policy. "Russia is Socialist, we are partly Socialist, America may believe in private enterprise. The great task of Great Britain is to weld these forces together to keep the peace," he declared at the 1946 Labour Party conference, pandering to the party's left wing (Schneer 1984, 204). The following year at the International Trade Organization negotiations in Geneva, he painted a similar picture for the American diplomats as well. Rather than "just another European country," Bevin argued, Britain was an imperial power that "could make a contribution to European recovery second only to that of the United States" (Hogan 1987, 46-9). None of this was cheap talk for behind these pronouncements there actually was a plan he called a "Third Force" - an all-but-Churchillian vision of Britain as the leader of a global bloc made up of the Empire and Western Europe, including France and its colonies. ${ }^{8}$

The Bevinite consensus had other country referents. A decade after the Attlee-Bevin debate, Chancellor of the Exchequer Harold Macmillan told a US diplomat that "Britain would become another Netherlands" if it failed to confront Egyptian president Gamal Abdel Nasser 
over the Suez Canal (quoted in McCourt 2014a, 70). Shortly afterwards he gave his first broadcast as prime minister:

$\leq \mathrm{Q}>$ Every now and again since the war I have heard people say: "Isn't Britain only a second or third-class power now? Isn't it on the way out?" What nonsense! In my lifetime I have heard the same old tale about our being a second rate power, and I have lived to see the answer ... Britain has been great, is great and will stay great, provided we close our ranks and get on with the job. (Quoted in Wallace 1970, 207-8) $\leq \mathrm{Q}>$

“Getting on with the job" spectacularly backfired in this case, yet Macmillan kept countering any talk of decline - first in the context of his "Winds of Change" shift towards Africa, then even more strongly vis-à-vis the European Economic Community (EEC), a.k.a. the Common Market: "Would entry confirm the image of Britain as merely another European state, no longer capable of playing a major role upon the larger stage of world politics?” (Sprout and Sprout 1963, 680, emphasis in original).

Similar questions abounded in many subsequent affairs, from Harold Wilson's devaluation of the pound and withdrawal from "East of Suez" - are we not "a sort of poor man's Sweden" now? (Mangold 2001, 120) - to the run-up to the Falklands War under Margaret Thatcher. Next came her famous Bruges Speech of 1988, in which she railed against "a European superstate," and after which some Eurosceptics began to refer to the EEC as "Belgium."

Fast forward through the end of the Cold War to Tony Blair's back to East of Suez era and we see yet more continuity. In the same year that the aforementioned Guardian editorial declared that "our national interest should be to play our important role as a true, trusted and 
committed European partner on the world stage," Sir Malcolm Rifkind, the man who served as both foreign secretary and defence secretary in the 1990s, wrote this: "The question for the UK and its Conservative led Government is whether it wishes to retain a global approach, or resign itself to the lesser status. Is it still prepared to act like France, or is it content to have influence comparable with that of Spain?" (Rifkind 2010). The question was once again rhetorical: no party or faction advocated a reduction in foreign policy ambitions to "the level of a Spain" (Christopher Hill, quoted in Gaskarth 2013, 126). In fact, if we are to judge from the interwar musings of figures such as Oswald Mosley, the longevity of "Spain" is second only to "Belgium" (Rubin 2010, 345-7).

Scratch any number of imperial-era shifts in Britain's geostrategic position - 1938, 1922, 1914, even 1873 - and you will no doubt find plenty of evidence of Britain's leaders obsessing about their country's greatness. Conversely, review discourses UK prime ministers left behind and you will find but two prime ministers who came close to entertaining the idea of abandoning pretensions to global leadership: Edward Heath, a Tory prime minister from 1970 to 1974 best known for his working-class origins, idiosyncratic views, and declaring a record five states of emergency, and Harry Perkins, the fictional protagonist of A Very British Coup, a 1982 novel by Labour left politician Chris Mullin. ${ }^{9}$

The Brexit era follows the same trend. "The feeling that Britain is not just another country and can never be 'another Switzerland,"' explains a British foreign policy textbook published in 2017, is still a constant (Sanders and Houghton 2017, 7). In 2018, Lord Richards, former chief of defence staff, spoke about a risk of the UK becoming "militarily and strategically insignificant" (Lester 2018) - or, in the words of Conservative backbencher Tony Baldry uttered earlier, a "Belgium with nukes" (McCourt 2014b, 165). (Baldry coined the phrase in 2010 in 
reaction to the National Security Strategy and the Strategic Defence and Security Review, the twin cost-cutting exercise that prompted the reaction from Rifkind quoted above.) At the risk of exaggeration, but with an eye on the rhetoric of the cabinet of the current prime minister, Boris Johnson, I would venture so far as to say that "Belgium" might continue to constitutionalize the British sense of exceptionalism even in a fragmented UK - that is, in a hypothetical future situation in which Scottish independence (and/or Irish unification) radically transforms the polity's constitutional settlement (and its military power).

Select comparisons with France, a fellow European major power likewise bursting with exceptionalism, uncover further foreign policy puzzles. Much like their UK counterparts after the war, authorities in the Élysée and the Quai d'Orsay sought to manage a crumbling empire while pursuing world power - a fact aptly illustrated by the Anglo-French invasion of Suez, for instance. Yet "Western unity" and "Cold War neutrality" meant different things in London and Paris, respectively. A decade after Suez, for example, French president Charles de Gaulle moved to first denounce Bretton Woods and call for a "return to gold" and then detach French forces from NATO’s integrated command. Why was this never an option in London? Simply put, British and French decision makers made different decisions when faced with similar structural pressures, whether in relation to debt, to decolonization, or to the US-Soviet face-off. ${ }^{10}$

Britain's zigzags vis-à-vis "Europe” are part of the same puzzle. As the British worldsystem all but disintegrated by the 1960s, entry into the Common Market became a new strategic goal - or rather, as most British leaders believed at the time, a new means for pursuing the old goal. This U-turn was never completed. Rather than championing or co-championing European federalism like their counterparts in Paris, UK governments remained committed to a "limited liability" policy, thus reinforcing a membership status that scholars have called "reluctant," 
"awkward," "aloof," "semi-detached," and "on the sidelines" (for overviews, see Daddow 2004; Ellison 2007; and Smith 2017). Moreover, as Christopher Hill (2019, 28, 34-5) observes, UK officials and politicians routinely underestimated the Europeans, based on an erroneous belief that the UK could always either exploit Franco-German tensions or be warmly welcomed as a tertium quid of the European project.

Contrast all this with the "reverential" attitudes towards the Anglo-American (a.k.a. UKUS) "special relationship" - a term some have argued is an Orwellian euphemism for a plot designed to turn Britain into America's "unsinkable aircraft carrier." ${ }^{\text {"11 }}$ Considering just how ruthlessly the US exploited the power asymmetry in this relationship, this view is not necessarily wrong. Recall, for example, that it was President Truman who, weeks after the Potsdam Conference, moved to terminate lend-lease aid, thus sparking the very first of the three major sterling crises that rocked the country before 1951. And yet, the special relationship carried on, with UK governments usually acting not as Greeks to America's Romans, as Macmillan famously wished it, but as "the warrior satellite" (Barnett 1972, 592): a spear-carrying Sidon to America's Carthage (Danchev 1998, 161).

Surely some UK politicians questioned these foreign policy parameters at some point? Some did. Far on the political right we have Enoch Powell, the man best known for white supremacist speechifying in the 1960s. As Camilla Schofield (2013) details, his other obsession at that time was what he called a "non-Commonwealth policy." Britain's overseas commitments, he wrote in the Times of 1 April 1964, "combine the maximum chance of involvement, embarrassment, expense, and humiliation, with the maximum effect" (quoted in Schofield 2013, 173). ${ }^{12}$ 
On the other side of the spectrum we have Labour left figures such as the long-forgotten Fenner Brockway, Konni Zilliacus, and C.A.R. Crosland, or the semi-forgotten early Robin Cook, the iconic Tony Benn, and Jeremy Corbyn, the party's Brexit-era leader. These politicians distinguished themselves as "mavericks" for many reasons, one of which was their willingness to imagine alternative foreign policy sensibilities for the country. In this, they occasionally found common ground with hardcore communists and members of the far-left Socialist Workers' Party, not to mention supporters of the New Left and the Campaign for Nuclear Disarmament. Yet even as they contemplated politics beyond the interests of the British state, neutrality, or pro-gender norms in foreign policy, most if not all of these "radical" leftists themselves struggled to imagine their country as just another Sweden. Instead, as Jodi Burkett (2013) has shown, they made claims of moral exceptionalism and exemplarity much as did liberals and conservatives. ${ }^{13}$ One of the most striking statements of this sensibility was made in 1948 and comes from none other than Aneurin (Nye) Bevan, the human engine behind the National Health Service (NHS): "The eyes of the world are turning to Great Britain. We now have the moral leadership of the world, and before many years are over we shall have people coming here as to a modern Mecca, learning from us in the twentieth century as they learned from us in the seventeenth century. ${ }^{14}$ ' Bevan remained convinced of British greatness even after the Suez fiasco: "this county is a depository of probably more concentrated experience and skill than any other in the world" (Harrison 2009, $96,543-4)$.

The fact there seem to be only a few, if any, ready examples of UK politicians accepting their country even as merely distinctive rather than as self-evidently unique and superior compels us to ponder the role of a ruling elite harbouring "delusions of grandeur" (Shonfield 1958, 97; see also, inter alia, Barnett 1972; Marcussen et al 1999; Haseler 2007, 2012; O’Toole 2019). 
This hypothesis has gone through a number of memorable articulations over the years. In a book published right after the victory in the Falklands, Anthony Verrier $(1983,321)$ pathologized the kingdom's foreign policy orientation with reference to the Alice in Wonderland syndrome, a perceptual disorder of the size of the patient's own body or its position in space that one English psychiatrist identified in 1955. And, in 1998, Alex Danchev $(1998,164)$ revisited Curzon's 1908 prophecy thus: "Britain is Belgium, though the British do not know it yet."

Analyses that connect the nature and causes of the formal foreign policy action of post1945 UK governments to delusional or illusory frames of references circulating in the Westminster, Whitehall, Fleet Street, and city corridors of power come in many forms. One could, for instance, accept that elite actors were to various degrees delusional, or at least illusionprone, and then proceed to argue that they managed the country's relative decline relatively well, including in foreign policy, or perhaps especially in foreign policy. ${ }^{15}$ One could also contend that the UK's illusion of power was only a second-order effect of assorted postwar and post-imperial adjustments made to meet the needs of finance and commerce - that is, of the owners of capital and property. ${ }^{16}$

Such nuanced approaches are vital but I think still incomplete. My argument here is that Britain's search for global leadership was always an expression not so much of bipartisan consensus, ruling-class interests, elite culture, or the "official mind" but of everyday selfunderstandings circulating in British society as a whole. ${ }^{17}$ Most important among those was British, and specifically English, exceptionalism - the idea that "we" are not just another part of Europe but are different from, and superior to, it: a kingdom so great that it must look out to a wider world. For all the complexity, heterogeneity, and contestation of meanings that twentieth century Britons attached to their nation, this sense of greatness remained ever-present, even if 
only tacitly - sort of the like prefix "Great" in "Great Britain." Greatness, in other words, was akin to a totem pole, the product of a vertically shared, deep-seated agreement between assorted elites and sub-elites, on the one hand, and the broader mass consumer public, on the other.

My aim in this book is simple. I want to provide a theoretically and methodologically grounded argument about the relationship between national identity and foreign policy against a backdrop of political, social, and cultural transformations in postwar, post-imperial British society and beyond. In so doing, I make an effort to build upon the insights of other scholars who have grappled with these themes and to redirect scholarly attention to an area I regard as fruitful for further research.

\section{Do Anglo-Saxons Have All the Best Tunes?}

Historically, IR scholars have tended to view states' foreign policies as a function of rational calculus based on objective self-interests. Some focused on the interests of national leaders powerful enough to bend the arch of history to their will. Others started with the interest of domestic and transnational groups and coalitions. Yet others foregrounded national interest as conditioned by systemic constraints and opportunities, such as the regional and international distributions of material power existing in objective reality. Beginning in the 1990s, however, the concept of self-interest has given considerable way to identity and nearby "constructivist concepts." The preface of Losing an Empire, Finding a Role, a British foreign policy textbook, indexes this change. In the first edition, published in 1990, David Sanders privileged "economic interests and realist balances of power"; in the second edition, published in 2017, Sanders teamed up with David Patrick Houghton to explain "complexity" and "new developments," including 
"new developments in IR theory": "The debate about EU membership which raged in 2016 in the run-up to the referendum illustrated the importance of national identity, domestic politics, and psychological perceptions of reality, not simply objective interests (however defined)."18

There is much to be said about the importance of each of these factors - variables, if you prefer - in the making and shaping of British foreign policy. In the same year that Losing an Empire, Finding a Role first appeared, William Wallace gave a speech at the Royal Institute of International Affairs, now better known as Chatham House, subsequently published in the institute's flagship journal, in which he, too, reflected on State Secretary Dean Acheson's famous quip. Wallace, then the institute's director of studies, agreed that Britain needed to define a new role for itself, particularly now that the Cold War was over, suggesting in the end that being "a link between Europe and the rest of the developed world" would do the trick. The problem, however, was that this new role was incommensurate with the prevailing "national identity" that is, with "concepts of our position in the world, from which flow presuppositions about which other nations are our natural allies or enemies, which share our values and which do not." Regardless of the crisis du jour and whatever the party in power, Wallace observed, Britain's policy and political elite appeared to be divided between "Anglo-Saxon" and "European" identities and identifications, but with the former having "all the best tunes." Acting as a bridge between Europe and the rest of the (developed) world was a good idea, but it did not come naturally to the British, he argued, because of, among other things, "the myth of English exceptionalism - a free country confronting an unfree European continent." ${ }^{19}$

Wallace, who would later go on to become Liberal Democrat peer Lord Wallace of Saltaire, was certainly not the only elite voice calling for a reorientation towards a European identity in the 1990s (Gaskarth 2014, 52). More important, his original analysis and subsequent 
publications on the same theme appear to have stood the test of time. At the time of this writing, Anglo-Saxons are Brexite(e)rs who cheer the nation's departure from the EU as the beginning of the great new phase in British engagement with what Churchill called the open sea. ${ }^{20}$ Europeans, then, encompass "Remoaners" ("Bremoaners"), who fret about an isolated and irresolute Britain, buffeted by geopolitical forces beyond its control.

More important, Wallace's article presages the rise of constructivist and interpretivist developments in IR theory. ${ }^{21}$ Like, for example, Roxanne Lynn Doty's (1996b) analysis of the construction of British sovereignty after empire published a few years later, Wallace's analysis eschews a static view of "Britain." Both authors similarly approach Britishness as a compound identity, meaning one containing not only multiple subselves - that of the British-Irish state as a single unit plus those of its constituent regions, with their particular national contents and contestations in tow - but also empire (Doty 1996b, 130) and/or its transnational afterlife (Wallace 1991, 70). Finally, both authors advocate a discursive approach. We cannot understand the evolving relationship between Englishness and Britishness, Wallace (1991, 79n38) suggests, without paying close attention to "coded phrases [that] carry depths of conscious and unconscious meaning."22

“Unconscious meaning” brings us to Contemporary Cultural Studies and Everyday Nationalism, two large and interdisciplinary literatures spurred by critical interrogations of modern British society by, respectively, Stuart Hall and Michael Billig. There, analysis begins with concepts such as Antonio Gramsci's senso comune, Raymond Williams's "structure of feeling," and Pierre Bourdieu's habitus and doxa - all social-theoretic reminders of the simple fact that most people carry out their social lives by following the assemblage of truisms accepted within a particular society. ${ }^{23}$ From these perspectives, "Britain" is not an aggregate of citizens 
who share common values or a common culture so much as a social and political construct that is performed, often unselfconsciously and unreflexively, through quotidian goings on.

For Hall (1981), who builds on Gramsci, hegemony is a system of rule that operates in and through the universalization and internalization of particular beliefs linked to particular social forces. ${ }^{24}$ So, to understand nationalism, racism, or related hegemonies, we must regard elites and masses as co-producers of this system, without the former simply manipulating the latter and without people being aware of their nationalism or racism. ${ }^{25}$ And national identity is constructed specifically through the stories which are told about "the nation" (Hall 1996b, 613).

Billig (1995) and other scholars of everyday nationalism are also focused on things people say, especially pronouns, demonstratives, locatives, possessive adjectives, adverbs, and tense, that point to the time, place, or situation in which a speaker is speaking. "Our confident role as a global power." "This empire was liberal." "They play by different rules." ${ }^{26}$ Known as deixis in linguistics, these "small words" - Wallace's "coded phrases" - speak volumes about the banality of nationalism, which means that they are precisely the type of "coded phrases" that Wallace suggested contain key information about Britishness.

Consider Wallace's $(1991,78)$ view of the relationship between identity and foreign policy: "States cannot survive without a sense of identity, an image of what marks their government and their citizens from their neighbors, of what special contribution they have to make to civilization and international order. Foreign policy is partly a reflection of that search for identity." This evokes late 1980s poststructuralist IR: state identity is not a "thing" and not simply "there" but, rather, constantly evolving or "becoming," including in and through foreign policy. We also see parallels with ontological security theory (OST), which is of more recent 
vintage in IR. ${ }^{27}$ Why seek Brexit at all costs? Why gamble with a referendum on EU membership in the first place, even after securing so many "opt-outs" on key parts of EU legislation? Why commit to a four-boat "Trident" missile fleet and/or to continuous at-sea deterrence? Why invest in two aircraft "super-carriers," while the Royal Navy has but seventyfive commissioned ships left in total and also while training across all three branches of the armed forces is being mercilessly cut? Why tolerate such a one-sided partnership with the US including with respect to the technology and facilities that enable the operational capabilities of not only Trident but also your biggest ships and the finest aircraft? Or, looking back to the twentieth century, why fight tooth and nail to protect sterling as the master currency and the antiquated system of imperial preference? Why support decolonization and then keep troops deployed east of Suez, halfway around the world from the home base? In purely materialist, objectivist terms, all of these policies - policies that Labour and Conservative parties largely shared or still share - might appear exceedingly costly and even illogical. Not so from the perspective of ontological security, or confidence in knowing who you are when going on in the world. Analyzing why the retrenchment from Asia took so long, Phillip Darby, writing in 1973, made a pointed observation: "the protection of India was part of an ingrained pattern of thought. It was above politics" (quoted in Self 2010, 166; see also Rees 2001, 38). If state survival is a function of predictability and order in an otherwise unpredictable world, then we should not be surprised to see the UK craving routines and relationships that feed its appetite for selfimportance even to the point of compromising its own material, physical security.

Significant complementarities exist with Ted Hopf’s (2002; Hopf 2013) “societal constructivism" as well. Foreign policy decision makers, Hopf argues, draw on national identity categories - classifications attached to the nation and members of the nation - to construct 
meanings, constitute action, coordinate their activities, and make claims in political life. While such practices are strategic, positional, fragmented, and deeply contextual, they also tend to be situated in particular discursive formations, or discourses, through which people articulate their experience of living in, and belonging to, nations. Written, spoken, or "simply" performed, discourses are shot through with power: Some are hegemonic or dominant, others subaltern or marginalized. To illustrate with Wallace's stylization, in 1990 the "Anglo-Saxon" discourse appeared to be deeply embedded in the media and education, whereas the "European" discourse circulated mainly among the elite. It follows that discourse analysis of Britishness at the level of society could go a long way in helping us outline the temporal, spatial, and ethical parameters within which British state action occurs (Hansen 2006, 40-5; see also Gaskarth 2011; 2013, chap. 4; Berenskoetter 2014, 264-6). Those working in the tradition of the "traditions and dilemmas" approach of Bevir and Rhodes (2003) would almost certainly agree (Daddow 2015, 73; also see Hall 2012; Bevir and Daddow 2015; Bevir, Daddow and Hall 2013; Bevir, Daddow, and Schnapper 2015).

An extensive literature has indeed emerged since the publication of Wallace's article that can help us examine the role national identity plays in shaping foreign policy choices. The wager I make building on this literature is that discursive fit can help us grasp the political dynamic between national identity contestation on the one hand and foreign policy on the other. Also known as resonance, match, or congruence, the concept of discursive fit is associated with multiple disciplinary and social-theoretic traditions (inter alia, see Vucetic 2011b, 12-13; Vucetic 2016b, 210-12; Holland 2013, 53-5; 2020, 69-73; Bevir and Daddow 2015, 279; Daddow 2015b, 76; Colley 2019, 2). In social psychology-inspired theories of identity management, for example, ruling elites succeed in reframing national identities as a way of 
achieving a more positive social evaluation only if their cues fit with the prevailing attitudes, opinion, and feelings of the public (Ward 2019). Likewise, in securitization theory, the framing of issues or events as security or existential threats depends, in part, on the willingness and ability of the target audience to accept the claim that its reality has changed such that extraordinary or emergency measures may be implemented (Croft 2012). And virtually all neoGramscians approaches would say that hegemony, although plural, complex, and fluid, is ultimately bounded by some sort of goodness of fit between the material structure and the predominant mental superstructure (Hall 1996a).

British foreign policy scholars have thought about discursive fit or similar concepts before. For example, writing with Christopher Tugendhat in 1988, Wallace draws our attention to "domestic acceptability," which they define as a constraint on British foreign policy-makers (Tugendhat and Wallace 1988, 101). Writing ten years later, Beatrice Heuser $(1998,5)$ argues that the emphasis on "independence" and "alliance solidarity" in British nuclear deterrence strategy persisted because it resonated with prevailing "collective mentalities" - and with more generally held British beliefs, images, allusions, and commonly held points of reference.

Identity-based explanations of British foreign policy rely more explicitly on discursive fit than do other explanations. In Amelia Hadfield-Amkhan's $(2010,204)$ nominally neoclassical realist account, national identity appears as "a political and cultural mechanism that obtains in foreign policy at moments of crisis.. ${ }^{28}$ The reason the pound-versus-euro debate of 2003 , to use one of her case studies, was never much of a debate, she contends, had to do with the utter misfit between the new monetary structure and the prevailing national identity in Britain at the time namely, a self-referential, particularist, and conservative "ethos of Englishness" (185; on the essential Englishness of British foreign policy identity, see also Doty 1996b). 
The same argument might be extended to "England's Brexit" (Barnett 2017, chap. 10) that is, to the failure of the pro-EU stance of the UK's official and unofficial mind to prevail over what many scholars argue were deeply rooted, and primarily English, objections to "loss of sovereignty. ${ }^{29}$ Accordingly, one good reason Remain lost the 2016 referendum and the general election of 2019 lies in the pervasiveness of the belief in the idea of British exceptionalism among voters concentrated in "England without London" and parts of English-speaking Wales.

Questions of Britishness, as Oliver Daddow and James Gaskarth remind us, have always kept UK leaders awake at night: "does the course of action fit in with Britain's view of itself and how it wishes to be seen by other actors in world politics? Would the British people support and identify with the policy? Which communities that Britain belongs to are affected by the issue at hand?" (Daddow and Gaskarth 2011, 17; see also Bevir and Daddow 2015, 274-5; Gaskarth 2013, 61). The authors' own interpretations of foreign policy-making under New Labour demonstrate this empirically (Gaskarth 2011; Daddow 2011), as do, for example, Jack Holland's (2013) analysis of Blair's rhetoric and the "War on Terror," and Nick Whittaker's (2017) examination of the "island race" trope in the context of the UK's struggles with globalization and with Brussels.

Role-theoretic approaches to British foreign policy recognize the importance of this dynamic as well. They do so through a number of analytical links: role conceptions or (discursive) self-understandings regarding the state's international role and purpose; role performances, or enactments of roles through policy choices and outputs; and role orientations, which are foreign policy strategies that take into account one's material and social constraints. Observing British foreign policy debates circa 2010, Gaskarth $(2014,48)$ distills six such orientations: "isolate, regional partner, influential (rule of law state), thought leader, opportunist 
interventionist and great power." These, he argues, are bounded by social expectations such that "governments that deviate from script can face punishment or the very least confusion from domestic audiences or other international actors." So, if the UK can no longer fight major wars alone, or even make division-sized contributions to deployments with allies, then a great power role orientation will only create inconsistency and confusion at the level of British identity discourses. ${ }^{30}$ The mutual constitution of identity and roles seems to be important even for David McCourt (2014a), who argues that the key to understanding post-1945 British foreign policy is not British identity but, rather, context-dependent expectations that emerge from the international process of "role-taking," "role-making," and "alter-casting," which relies on discursive fit. His key finding is that the US and France continually cast Britain in a "residual great power" role. But apparently so do the British people themselves: McCourt also finds British leaders "framing their behavior in certain ways to make it fit" with prevailing ideas "at home" - in the House of Commons, with the media, and with public opinion. ${ }^{31}$

Building on the above, we might say that any theoretical framework that purports to trace how political authority in British foreign policy is "legitimized," "narrated," "framed," or "performed" requires an account of discursive fit. The problem is that most theorists focus only on the manoeuvres political elites use to dominate meaning-making and to control debate. This I find reductionist. Here is a much-quoted paragraph from Sir Oliver Franks's Reith Lecture 1, broadcast on BBC Radio on 7 November 1954:

The action of a Great Power can decisively affect the fate of other Great Powers in the world. It is in this sense that we assume that our future will be of one piece with our past and that we shall continue as a Great Power. What is noteworthy is the way that we take this for granted. It is not a belief arrived at after reflection by a conscious decision. It is 
part of the habit and furniture of our minds: a principle so much one with our outlook and character that it determines the way we act without emerging itself into clear consciousness. (Franks 1954)

Franks's six-part Reith Lectures series offers a superb glimpse into the postwar official mind, partly because the lecturer carried them with all the gravitas one might expect of a diplomat who had helped to negotiate both the Marshall Plan and the North Atlantic Treaty. ${ }^{32}$ It is also a startlingly accurate prediction of the future. Even after empire, he declared, the kingdom would stay the course. ${ }^{33}$ But in the above passage we see that Franks lectured as a sociologist, too. Great power pursuits are a matter of habit, a belief so routinized and solidified that most people never even stop to think whether the label still makes sense. This is a conceptualization of discursive fit with a twist, one in which mass culture and "high" politics work together to generate Britain's mental furniture.

Following this model, elite agency is deeply constrained by what is intelligible and accepted in civil society at the level of "who is who," that is, in the everyday discourses of who "we" are and who "they" and "Others" are, or were, or aspire to be. Accordingly, a foreign policy (framing, narrative, performance) will make sense if it (continuously) resonates with the quotidian habits of the nation's elites and masses (Gaskarth 2013, 92; see also Hopf 2010). Attlee's decision to quit India in 1947, Macmillan's push for EEC membership in 1961, Wilson's “creative incompetence” during Turkey's invasion of Cyprus in 1974, or Thatcher's welcome of Zimbabwe's independence in 1980 - a few examples of unconventional, far-sighted British foreign policy action - were all contentious but not absurd. Conversely, a foreign policy performance characterized by a complete discursive misfit lacks intelligibility, while one that fits only a marginal discourse lacks acceptability. Either way, that policy performance lacks 
legitimacy and likely cannot go on for long - think of that moment during the Suez Crisis when the government in London found itself near-isolated internationally (unacceptable), or, for that matter, a counterfactual situation in which a post-1945 government decided to pay reparations to former colonies (unintelligible).

Reconstructing the habit and furniture of British minds is a worthy goal because it can help us make and evaluate non-circular claims about why some foreign policy frames and narratives - and so some foreign policy decisions and strategic choices - resonated and were supported, while others struck a false note and were rejected. Interpretivists would always say that "Suez" did not speak for itself, and neither did Britain, certainly not with a single voice. Instead, various political actors - primarily but not exclusively those at the apex of the Westminster-Whitehall system - fought hard to frame the crisis in some ways but not in others. But what a good interpretivist account of the crisis also needs, I argue, is an independent account of what then British society instinctively knew and felt about "us," "them," and "Others."

Discursive fit can be, and often is, conceptualized as a causal mechanism. That said, fit between foreign policy on the one hand and prevailing discourse or discourses on the other does not, and cannot, imply a perfectly linear one-to-one match between a particular construction of national identity and a particular foreign policy (Gaskarth 2014, 47). Instead, discursive fit means that dominant discourses construct truths and realities within which policy is made and unmade. This is precisely why many if not most constructivists draw a distinction between why and how (or how-possible) questions. To go back to Doty (1996a, 4) again, why questions put aside identity, while how questions problematize it. As in: Why did the government replace the UK nuclear deterrent with another US-made, US-controlled system? Versus: How did the act of throwing the country's strategic lot with Washington become normal and legitimate? The latter 
question is far more focused on productive power - that is, on the production of particular subjects, objects, and interpretive sensibilities upon which the (nuclear) special relationship rests (Croft 2001b). ${ }^{34}$

All this being said, basic factual questions are still important, especially for an account that sets out to cover colonial, Cold War, and post-Cold War contexts - namely, the period from 1950 to 2000. Although no professional historian -cultural, diplomatic, or otherwise - would recognize this book as history, I do borrow historical methods, scale, and sensibility (on historical IR, see Little 2008; Lawson 2012; Leira and de Carvalho 2016; on discursive construction of temporal identity, see Hansen 2006). Consider the following questions taken from the conventional historiography of decolonization, as articulated by Wendy Webster (2003, 3): "What was the impact on narratives of Britishness and Englishness of a diminution of British territories and a contraction of its frontiers? How were the legacies of empire portrayed? Were habits of mind associated with colonialism dismantled as rapidly or as extensively as British colonial rule, or did they outlast the end of empire?" We could add a few more: To what extent did Suez or the endless crises of the 1970s affect the identity repertoires through which British society brought itself to life? Did the government push into the Common Market follow significant transformations in dominant structures of feelings at either elite or mass levels? Was the Thatcherite "New Right" successful in redefining the national senso comune, as Hall famously predicted it would in January 1979, four months before Thatcher came to power? Did the new 1988 National Curriculum for England, Wales, and Northern Ireland in any way disrupt the dominant "Anglo-Saxon" discourse, as Wallace hoped it would? Did shifts in the gendered and racialized reproduction of the British state and society correlate with any discernible change in Britain's foreign policy ambitions? 
Engagement with these and similar questions is necessary in my account for two reasons. The first is essentially Gramscian: if, as the Italian philosopher argued, powerful elite-run institutions, such as political parties and mass media, reproduce a national common sense that is shared by the elites and masses, it is likely that the identity of a country will remain stable for some time. But if agreement on central categories is thin and highly contested, such that said "vertical" consistency is missing, national identity is likely to remain fluid, with discourses changing in accordance with historical action. ${ }^{35}$ Either way, a broader and deeper account of Britishness is a precondition for understanding, not only in terms of continuity and change but also in terms of policy alternatives that never came within the reach of actual policy.

The second reason relates to what IR scholars variously call "recursivity" and "looping effects" (Jepperson, Wendt, and Katzenstein 1996, 62; Whittaker 2017, 10; Doty 1996b; Mattern 2005). The basic notion here is that national identity simultaneously influences and is influenced by state policy action, and that both processes have continuous and overlapping relations with the structure of the international system. Analyses of foreign policy conducted from the perspective of "tradition and dilemmas" put these dynamics at the forefront, too: to what extent to traditions evolve upon the resolutions of dilemmas? (Bevir and Daddow 2015, 275, 283; Bevir, Daddow and Schnapper 2015, 8). Therefore, in addition to examining how discourses of Britishness influenced the shape of British foreign policy performances in certain historical contexts, I also pay due attention to how British foreign policy performances wrote British identity. This brings into play counterfactual reasoning - that is, reflection on how the British decision makers would have responded to key watersheds had identity topographies been different at the time or had they evolved differently. 
To sum up: I consider British foreign policy as a dynamic, three-way interaction between decisions makers themselves, discourses of British identity into which decision makers are socialized and within (or against) which foreign policy is made, and broader processes generational, cultural, and international - that confront decision makers with different challenges within this nexus. Now I turn to the methodology I use to evaluate this framework.

\section{Finding Britishness}

All too often in the social sciences, national identity is approached via positivist methods. Scholars come up with a list of national identities they expect to find in a community and then they proceed to look for them via public opinion surveys, for example. The interpretivist goal, in contrast, is to allow the subjects to speak for themselves as opposed to having the analyst speak for them. We see this sensibility at work in a number of recent studies of British political culture and citizen understandings of politics. Nick Clarke, Will Jennings, Jonathan Moss, and Gerry Stoker (2018) mix textual data from Mass-Observation studies - that unique archive of British everyday life - with a quantitative analysis of responses to public opinion surveys to examine repertoires of cultural resources that defined British "anti-politics" in the postwar period. Matthew Jones (2018) looks at what Mass-Observation reports said about the nation's wars in the Falklands, the Gulf, Kosovo, Afghanistan, and Iraq. Thomas Colley (2019) relies on interviews to examine how ordinary British citizens narrate stories of Britain's role in war and Britain's identity more generally.

I reconstruct the content, contestation, and evolution of post-1945 Britishness using inductive discourse-analytic research that my collaborators and I conducted under the auspices of 
Making Identity Count (MIC), a project to assemble the first constructivist database of national identities for use in IR and in social sciences and humanities more generally. ${ }^{36}$ The analysis is based on an archive of textual artefacts sampled in six ten-year intervals: 1950, 1960, 1970, 1980, 1990, and 2000. The texts are drawn from an assortment of everyday experiences and institutional centres in the UK, with one eye on different forms, modes, and media of elite versus mass communication. Leadership speeches; newspaper editorials, op-eds, and columns; and secondary school history textbooks were taken to be sources of elite discourse, in contrast to more mass-oriented letters to the editor to said newspapers, novels, and commercial feature films. Table 1 is a summary of the documents used, with further details in Appendix A. ${ }^{37}$

\section{TABLE 1 ABOUT HERE}

My sampling strategy raises a number of questions. To begin with, the elite-mass distinction is, sociologically speaking, loose. This is by design. Rather than differentiating between policy and cultural elites, or between elites and sub-elites, or between different types of masses, I simply collected texts that can be credibly described as much talked about, highest circulating, must-read, bestselling, or most watched, the theoretical principle being that elite and mass publics are "co-authoring" the national identities contained therein. The former's political domination over the latter - even as "mere" consumers of texts - is thus an empirical question.

Next, the term "British" was invested with modern meaning through imperial projects

dreamed up in England - from the seventeenth-century colonization of Ireland to the 1707 Act of Union between England and Scotland and its subsequent westward enlargement into Ireland in 
1800. Always centred on London, this union of unions was furthermore constitutionalized as a multinational, polyglot, and hegemonic empire whose patterns of historical development bear a resemblance to similar polities elsewhere. ${ }^{38}$ The Britain I analyze in this book, however, refers to its post-1945 iteration - what Edgerton (2018b) calls "national UK." ${ }^{39}$ This is in line with Gaskarth's textbook definition of Britishness: an overarching national identity shared by many members of the UK's sub-state nationalities within the UK as a polity (Gaskarth 2013, 197-8n1; cf. Schnapper 2011, 3-4; more generally: Gilroy 2004; Ward 2004).

One advantage of this definition is that it is sufficiently sensitive to the variability of both "British citizenship" and "national UK" in the period under study. ${ }^{40}$ Indeed, the focus on national identity categories must not preclude paying due attention to how non-national categories become articulated within a British "we." That being said, the reader will rightly inquire about the Manchester Evening News and Liverpool Echo or, in nod to a proper "four nations" approach, the Swansea-based South Wales Evening Post and Scottish history textbooks. Why produce another study that treats the English as the British nation rather than as $a$ British nation (Gamble 2003, 3)? An equally strong case can be made for a less print-centric archive, not least because radio and, from 1970 onwards, television were at least as popular as movies. ${ }^{41}$ So, where are documentaries, soap operas, sitcoms, the FA football cup finals, and cooking shows? And why not sample mass discourse from Mass-Observation, too?

My defence here rests on both principled and pragmatic reasons: principled, because my analysis deliberately privileges England and, more specifically, London as the dominant site for the discursive production of national UK; pragmatic, because an inductive recovery of a repertoire of ideas from which the postwar elites and masses drew to identify themselves as British is time-consuming even for a single year, much less for six. Doubtless, adding the 
Liverpool Echo, the BBC's To The Manor Born and That Sinking Feeling, and Bill Forsyth's Glaswegian comedy film would have enriched and diversified the corpus of texts for 1980. But it would also have required hundreds of more coding hours. (The multimodal nature of discursive meanings contained in film and television suggests that a single scene might contain dozens of relevant references. $)^{42}$ As for ordinary people-authored texts from Mass-Observation, no such material exists for this particular year - the project was discontinued in the mid-1960s and was revived only in 1981. So, while I would agree that the historical documents I use are far from optimal, I would also say that optimal sources do not exist for the issues explored in this book.

The reader will note that my analysis heavily intersects with some social identities, specifically those of privileged white men of a certain age and class. Among the leaders whose speeches are examined here, for instance, all but one were white men and all but one were Oxford-educated. The rest of the corpus is thankfully less Oxonian, yet there, too, the overrepresentation of white men is nearly as overwhelming with regard to both authors and characters. ${ }^{43}$ But locating the discursive imagination and articulation of a nationalist UK in its white "malestream" is not necessarily a methodological shortcoming since it gives me an opportunity to apply and evaluate select ideas drawn from feminist and postcolonial scholarship. From the bomb to assorted invasions and reinvasions, postwar British foreign policy produced and reproduced gendered hierarchies not only "abroad," as between the West and non-West, but also "at home," as when some leaders feminize and emasculate their opponents by calling them weak, risk-averse, or backward (McClintock 1995; Doty 1996a, chap. 5; Doty 1996b; Webster 2005; Basham 2018). 


\section{FIGURE 1 ABOUT HERE}

Figure 1 is a step-by-step visualization of the analytical process. The aforementioned sampling strategy is shown as step 1. In step 2, dubbed finding identities, my collaborators and I began with an effort to put aside any prefabricated ideas about what Britain meant or what it

meant to be British. ${ }^{44}$ We then used three basic inductive coding rules to code every reference to "we" and "us" that appeared in the actual texts: valence - that is, positive, negative, neutral, or ambiguous; aspirational/aversive - that is, whether or not the identity is one that the Self aspires to or is trying to avoid; and significant Other, which refers to any broadly national categories to which the Self compares itself in time and space (i.e., not just other countries but also historical events, such as the Second World War or the Scottish Enlightenment, or ideologies, such as liberalism or communism). The method forced us to differentiate mere themes ("leisure is good") from actual national identity categories ("the English like good leisure") as well as to examine local particulars and contingent meanings that might otherwise be lost when analysis accepts either platitudes ("the British are militaristic") or statements drawn from the media or public opinion research (“young Britons rank Spain as a top vacation destination”).

By way of illustration, here is my coding of "No Trumpets," an editorial published in the Daily Express on 15 September 1960:

Where are the drums? Where are the trumpets? They do not sound for today's preliminary session of the Commonwealth economic conference.

The sad truth is that nothing of importance is likely to come out of this conference. It may be that Empire lands like New Zealand, already worried about its tariff preferences, will learn that the British Government means to reduce those preferences still more. 
The Government is more concerned with getting into the same trading system as Dr. Adenauer than with developing the Empire trading system.

Who supposes that Dr Adenauer would give a fig for Europe if he had an empire?

In this text I observed four discrete identity categories: imperial, Germany, Europe, and trading. I coded imperial as positive, with a note about the empire-Commonwealth interchange in which New Zealand appears to be subsumed under the British Self. Germany and Europe were both significant Others. The former, epitomized in the figure of its chancellor, was negatively evaluated because of its ambition (regional domination) and inferiority (no empire). The latter was merely neutral. Finally, though Britain was a trading nation, its aspiration was not free trade so much as "the Empire trading system."

Subjecting the entire 1960 corpus to the same procedure, I distilled numerous other identity categories from what the texts said about who or what is excluded, and where the boundaries between "us" and "them" were in those days versus where they were before and where they might be in the future. Inspired by Gramsci's theory of common sense, I likewise looked at the meanings of "the good life" - what was a desirable way of life in 1960, a just and normal way of ordering British society, its politics, economics, culture, spirituality, and so on. While reading and coding, I also ran a tally of raw identity category counts and their prevailing valence, first within texts and genres, and then across all five genres. This yielded a long list of identity categories -155 in this case - arranged by salience, from most frequent to least. The top categories - the top 25 percent of all identity categories coded and counted for 1960 - were the ones I discussed in detail, with ample examples provided. The category "patriarchal" topped this 
list, followed by "class-based," "statist," "modern," "just," "technological," "anti-Soviet," and so on.

In figure I.1, these two steps stand as "contextualization" (step 3) and "intertextualization" (step 4). The purpose of this method is to balance the interpretivist commitment to an inductive recovery of British identities in their local, historically constituted contexts with a method that is more systematic, transparent, and replicable than is usually the case with more traditional interpretivist measures of importance and prevalence of intersubjective meanings ${ }^{45}$ Looking at the findings from across all six years at once, I could thus identify postwar Britain's most significant Others as well as a dozen cross-cutting and reoccurring identity categories (categories in brackets refer to their intersubjective nearsynonyms) across political, cultural, economic, and social dimensions. These include statist, modern, class-based (unequal), democratic, patriarchal (manly), orderly (civilized), capitalist, partisan, influential, declining, just (fair), and benevolent. I could likewise observe identities that were specific to one or more years under study: post-imperial (from 1960), educated (to 1970), diverse (2000 only), and so on. ${ }^{46}$

The final step in the analytical process, step 5, involved a reconstruction of a British identity topography, or a map, for each year under study. This step was the most theoretical in the sense that I clustered coded identity categories into prevailing (hegemonic, dominant) and alternative (counter-hegemonic, subaltern) "discourses of Britishness" according to the observed main discursive patterns: elite-mass unity versus elite-mass division, most significant Others, and different identifications alongside political, economic, social, and cultural dimensions of what Britain or British meant in a given year. For 1960, for example, I identified three: a dominant 
discourse, which I labelled Modern Britain, and its two challengers, Socialism and Traditionalism.

I did this for all six years under study, thus completing what we might call a comparativestatic analysis (in which a compare-and-contrast is performed at different points in time but without accessing data corresponding to the in-between period). This allowed me to take a transversal view of the evolving British "we" and to see how different discourses might overlap and how past discourses influenced future ones (Hall 1996c, 202; Hansen 2006, 55-66). A quick summary of the main findings shows that British society perceived and conceived Britain as fundamentally special: modern and prosperous, free and democratic, fair and just, capitalist and industrial, beautiful and orderly, and peaceable and benevolent. These categories of identity were "vertically shared": they circulated not just among the ruling elites but also, to various degrees, among the masses, and not just in what I call hegemonic discourses - I give them labels such as "Recovery" and "Adaptable Britain" - but also in counterhegemonic discourses such as "Socialism" and "Traditionalism." They were also "sticky": they existed in all six years under study. So, however heterogeneous the understandings of Britishness and however radical the generational and cultural transformations in society, the British "knew" they were, or were supposed to be, unique. This construction could also be spatial, temporal and/or ethical, as in a claim that our empire was not only the largest and historically most consequential, but essentially and uniquely liberal. British exceptionalism, then, is the first essential component for understanding the drive towards global power in British foreign policy long after such an approach became all but unaffordable financially.

Britain - the noun I use to talk about a state that in fact prefers to be called "the UK" was predominantly, though not exclusively, an English project. This was more explicit in 1950, 
when every other text seemed to conflate Britain (England, Wales, and Scotland) and even the United Kingdom (of Great Britain and Northern Ireland) with England, than after the 1970 Scottish devolution referendum, much less after actual devolution of power under New Labour. Yet England was always Self, except when it referred to an unhappy past version of itself, as in "Victorian England," while Wales, Scotland, and Ireland, both north and south, wavered between Self and Other, depending on the context. Similarly persistent was the deictic centring on the UK and, more specifically, on England in phrases such as "the Home Counties," "the island nation," "the mainland," "the British Isles," and, indeed, "the British."47

The failure of the English to conceptually separate themselves from other British nations went hand in hand with a tendency to view empire as something that England/Britain possessed, not something that England/Britain was. This configuration changed from 1960, with the rise of national as well as of postcolonial and post-imperial self-identifications - a "Socialist" embrace of the Movement for Colonial Freedom, for example. It changed even more in 2000, when "multiculturalism" was grafted onto cosmopolitanism to further emphasize the nation's diversity, inclusivity, and tolerance. What stayed the same was a practice of separating the state from its violent imperial and colonial past - and from coloniality as a present condition - and the nation from the presence of non-white citizens. And whereas mainstream discursive practices eventually came to address sexism overtly and often in considerable depth ("we are a queendom now"), this was never the case with racism, where the most common response was "we are not as bad as others."

Empire and its legacies configured the world map throughout and with variable effects on Britain's ontological security. The West was white, meaning majority populations of Western polities were always racialized as white. Australia, Canada, and New Zealand were proper 
"British," or "white Commonwealth," countries and so peaceful, orderly, well governed, or just simply lucky. The US, a.k.a. America, was Self and Other at once - not a Canada on steroids but certainly part of the shared "English-speaking world," to use Churchill's parlance. Related, while virtually everyone acknowledged American presidents as true leaders of the West, only a minority accepted that the special relationship was the flying buttress to Britain's own leadership and privileged international status.

United States's liminal status never extended to other former colonies, irrespective of how much they shared with Britain its history, politics, culture, economics, law, media, and familial ties. The "New Commonwealth," later also described as "the Third World," was consistently on the outside, as were, with various degrees of separation and aversion, apartheid South Africa, the Irish and French republics, the two Germanys (West and East), and "Europe" (in latter years also known as "Brussels"). Soviet Russia was as menacing as Nazi Germany, the defeat of which was a constant source of pride and of moral supremacy. Neither India nor China were coded as top identity categories.

Britain also viewed itself as declining. Though present in all years, this identity category was most systematically repeated and reworked in 1970 and 1980, when the kingdom's industrial economy and its masculine ideals - strength, pride, and independence - came under severe attack. The question of what needed to be done about decline was subject to contestation, both intra-elite as well as elite-mass. In some years, elite celebrations of economic progress (as in Recovery) or socialist institutional life (as in Socialism) struggled to convince the masses, committed as they were to certain traditions (as in Traditionalism). In other years, the discourses advanced by Thatcher and her adherents ("Thatcherist") regularly clashed with civil society's memories of le temps perdu. However, the more important finding is that most discourses in 
most years were still bloated with affirmations of, and aspirations to, collective greatness scientific, civilizational, moral, and so on. Continuously reproduced and circulated, "greatness" shaped how the British experienced historical change in the first place.

Understanding multiple and layered elements of British identity in this way is useful, I argue, because it helps us recreate the ever-changing daily experience of both the governors and the governed - that is, both the elites and the masses - and therefore the deeper intersubjective structure within which Britain's leaders operated in the post-1945 period.

\section{Finding British Foreign Policy}

The constructivist framework I develop and evaluate in this book sets out to illuminate British relations with the rest of the world rather than particular British foreign policy choices. Some empirical focus, however, is necessary. I begin with foreign policy debates - public exchanges about merits and demerits of particular British foreign policies or policy situations. If my framework is right, these debates should reflect and reinforce elite-mass connections and disconnections at all times. Accordingly, the object of discourse analysis now shifts from civil society to "the British foreign policy elite," which is a convenient shorthand for texts produced by influential individuals embedded in Whitehall, Westminster, and the London media, a.k.a. Fleet Street (Sanders and Edwards 1994, 415-16; cf. Towle 2009).

To put temporal and spatial constraints on debates, I broke each of the six decades under study into four "events," for twenty-four in total, as listed in table I.2. 


\section{TABLE 2 ABOUT HERE}

In principle, events include anything from external shocks and crises, government policy U-turns - think Suez or East of Suez - to new information, knowledge, and broader processes that mark the modern world, whether in the economy and politics, in ecology and technology, or in migration and ethics. "Eventfulness" is a useful perspective from which to view history in order to observe temporality and the logic transformation. ${ }^{48}$ War is a classic case because winning in war make states ontologically secure - just look at the many ways in which Thatcher tried to position the success of the Falklands War as the decisive locus of Britishness. Conversely, endless, unwinnable wars on terror are likely to produce ontological anxiety (Subotić and Steele 2018).

In this study, I focus specifically on "foreign policy events," which I selected in accordance to three selection rules: temporal proximity, spatial diversity, and paradigmatic relevance (Appendix B, figure B.1). The first rule has to with the underlying causal logic: the idea that the temporal gap between an identity topography and the corresponding event should be shorter rather than longer. This is why, for example, I decided to look at de Gaulle's "first veto" of 1963, not his "velvet veto" of 1967.

The second rule follows from the aforementioned wager that topographies of Britishness can shed light on multiple developments in British foreign policy during a given period. Accordingly, for each decade under analysis I selected events corresponding to each of Churchill's famous "three circles" of British foreign policy: one for the British Commonwealth and Empire, one for the United States and other "English-speaking peoples," and one for "Europe." As many scholars have noted, "three circles" was never so much a heuristic device for 
describing the competing priorities of British world power as the reigning "framework" that configured postwar Britain as sitting at "the very point of junction" of these three spaces and the go-to "conceptual prism" through which, for decades, actual foreign policy events were processed. ${ }^{49}$ The expression "squaring the circles of British foreign policy" is still being used (Hill 2019, 8, 180).

Paradigmatic relevance refers to events that have already been used to evaluate or highlight constructivist and interpretivist claims concerning postwar British foreign policy. ${ }^{50} \mathrm{I}$ followed this rule on the assumption that my book would not be readers' first (or last) exposure to the historical period, debates, and events under discussion. This led to two benefits and one drawback. The first benefit is range. In looking at the event now simply known as Suez, for example, I draw on studies of the crisis attuned to the role of political rhetoric and discourse and, for additional context, on studies dealing with the press and the parties, including their "backbench tribes" (e.g., Onslow 1997; Mattern 2005; Towle 2009; McCourt 2014b; Thomas and Toye 2017). Similarly, I pay close attention to secondary interpretations of "paths not taken," "missteps," and "missed opportunities," meaning the conditions under which British leaders could have legitimately broken alternative paths, such as "more Europe" or alignment with Washington à la française.$^{51}$ This literature provides crucial insight into the policy options British leaders considered before they chose some and rejected others.

The second benefit is greater attention to "silences" - vital areas not addressed in policy discussions. As Heuser (1998, 5, emphasis in original) notes, actual foreign policy debates were rare in postwar Britain: "Typically, basic concepts are not spelled out, but taken for granted, just as consensus on them is taken for granted." Attention to the unspoken, implicit references can be found in most such analyses but especially in discourse analytic accounts. I naturally heed the 
contextual aspects of said silences, as when all decision makers agreed that foreign policy is special policy because of, for example, "immutable structural dictates" or "the need for secrecy. ${ }^{52}$

Reliance on secondary sources poses assorted risks: priming, bias, misinterpretation and omissions, among others. I minimized this drawback in two ways. First, I consulted secondary literature only after completing steps 1 through 5 (figure I.1) for all years under study. Second, to estimate the influence and centrality of the people quoted and cited to the debates under study, I worked with multiple histories and analyses, occasionally analyzing primary sources directly. Whenever major interpretative differences emerged I flagged the reader in an endnote.

Wading beyond foreign policy, I added a selection of defence reviews to my analysis as well. I did this for two reasons. First, as Denis Healey, one of most influential postwar defence ministers, remarked, defence policy often "came to determine foreign policy due to the fact that all commitments were considered to be vital" (quoted in Rees 2001, 30). In other words, there is evidence that high military expenditure had the effect of determining the nature of Britain's post1945 global role rather than the latter determining the degree of the former. Second, defence reviews, as declaratory policy (Dorman 2001, 9), are in principle deeply "eventful." Produced by bureaucrats under the direction of the government (minister) of the day and then presented to the legislators and the public, these documents - also called statements on defence or defence white papers - are indeed elaborate documents that address the past, present, and future of defence policy, laying out both geostrategic rhetoric (cf. Porter 2010) and (the ever more difficult) budgetary considerations. As such, they tend to prompt public contestation about national priorities and policy trade-offs, thus giving constructivist researchers yet another vantage point 
from which to analyze the (putative) pathologies in Britain's relations with the rest of the world (Croft 2001a).

Table I.2 lists at least one defence review for each decade (for bibliography, see Appendix B). In addition to analyzing the textual content of each, I combed through relevant historical studies to determine what parts, if any, of said documents were publicly debated, and with what effects for my analysis of the identity-foreign policy nexus overall.

Together, these methodological choices provide a chronologically structured, geographically diverse, and relatively efficient discussion of postwar British foreign policy. In addition to crossing colonial, Cold War, and post-Cold War contexts, the chapters that follow thus cover Britain's relations with the individual states of the First, Second, and Third Worlds, both bilaterally and within multilateral international institutions. And although "security themes" predominate, the empirical testbed is still broad enough to cover a myriad of separate yet, from my perspective, conspicuously intertwined phenomena.

To sum up, my goal in this book is to demonstrate the validity of a properly constructivist reading of Britain's international (mal)adjustments after 1945. Although many British foreign policy analyses now routinely incorporate identity, discourse, and habits, they rarely attempt to recover these intersubjective structures inductively, much less over time and across the elitemass divide. This is a lost opportunity from both theoretical and analytical viewpoints for only a wide-angled lens allow us to see patterns of continuity and change in said structures as well as to locate relevant parallels among them. 


\section{Plan of the Book}

The next six chapters are arranged chronologically, covering the six decades between Attlee's "New Jerusalem" and Blair's "New Labour." Each is structured as a three-part discussion:

- Summary of the main findings and arguments.

- Discussion of top British identity categories with examples drawn from the corresponding MIC report. For presentational purposes, I plot top identity categories measured by frequency in word clouds, where larger and darker words represent categories that were coded as most frequent.

- Reconstruction of a topography of contemporary Britishness and a reconsideration of select foreign policy events in light of said topography.

In the conclusion, I summarize the findings and compare them to other accounts of British foreign policy. And while this discussion is primarily about competing interpretations of the past, I end on a speculative note, briefly considering what the future might hold in store.

\section{Notes}

${ }^{1}$ The first aphorism, which likely belongs to late Belgian prime minister Paul-Henri Spaak, came from Danish finance minister Kristian Jensen (Boffey 2017) and then also from Spanish foreign minister Joseph Borrell (Sharma 2019). The second comment came from the president of the EU's European Council Donald Tusk (Reuters 2019).

${ }^{2}$ The phrases are from Prime Minister Theresa May (Blagden 2019; Daddow 2019; Ward and Rasch 2019).

${ }^{3}$ This is a vast literature that begins with Gallagher and Robinson (1953). 
${ }^{4}$ Craig and Radchenko (2008, 79-80). See also Harrison (2009, 9); Hopf (2012, 79-80); and Shifrinson $(2018,1)$. On status recognition as a function of assorted competitive performances in international society, see Røren and Beaumont (2019); Ward (2019); and Murray (2019).

${ }^{5}$ The definition is from Shifrinson $(2018,13-15)$. In his estimation, the UK's European capabilities declined from 11 to 14 percent to 8 percent and from 22 to 33 percent to 20 percent vis-à-vis the US (16, chap. 2). For a range of alternative characterizations of Britain's great powerhood, see Blagden (2019, 4 7).

${ }^{6}$ Gamble (2000, 5; 2003, 27-8). See also Holland (1991); Clarke (2004 [1996]); English and Kenny (2000); Hall (2000); Croft (2001a); Hall (2012, 4); Simms (2016, chap. 9); Tomlinson (2017, chap. 2); and Green (2020, chap. 1).

${ }^{7}$ On the consensus and its subsequent iterations, see McCourt (2014a, 4; 2014b, 165); Self (2010, 6, 367); Heinlein (2002, 137); and Harrison (2009, 5, 115-16). Note also that the descriptor "postwar" works to elide the history and politics of imperial decline (Bailkin 2012; Schofield 2013; Burkett 2013).

${ }^{8}$ Bevin pitched the notion to the French and continued to champion it well into 1949. He was not alone. Some Third Forcers in London argued for territorial expansion (Bevin had an eye on the Italian colonies in particular), others for a rapid industrial development of empire, and still others for bringing select European countries into the Commonwealth (Bevin's "Western Union" speech of 1948 can be read this way). France had its Third Forcers at the time too. See Barker (1983); Vickers (2003); Daddow (2004); Darwin (1991); Heinlein (2002); Deighton (2013); and Grob-Fitzgibbon (2016).

${ }^{9}$ The sequel, The Friends of Harry Perkins, was published in March 2019. In Mullin's vision of the future, set in 2025, Brexit negotiations are still inconclusive, the Labour Party is in continued opposition, and the US is at war with China. Note that Haseler (2012) counts Attlee, Wilson, and Blair among potential change agents. 
${ }^{10}$ Larsen (1997, chap. 1); Bell (1997, chaps. 5-8); McCourt (2014a, 5, 182n24); Hill (2016, 395; 2019, 137-9); and Thomas and Toye (2017, 230-7). On comparative post-imperial pathways more generally, see Thomas (2014); and Buettner (2016).

11 "Reverential” is from Gaskarth $(2013,68)$. "Unsinkable aircraft carrier" is Churchill's phrase (Campbell 1986, 1); Orwell actually preferred “Airstrip One” (Vucetic 2011b, 1).

${ }^{12}$ Powell's was in fact a double critique of British foreign policy: against the idea of global leadership whether via the Commonwealth or the Common Market - and against the nineteenth-century idea of a free-trading little Englandism (Schofield 2013; see also Shilliam 2018, 96-106; Kenny and Pearce 2018, chap. 4).

${ }^{13}$ On Labour's attraction to the Swedish model, see Harrison $(2009,119)$. Exemplarity can be defined as "the social process through which standards of conduct are formulated, sustained, and re-worked" (Noyes and Wille 2020). On the UK case, see Harrison (2009, 544-5; Harrison 2010, 547-8); and Gaskarth (2014, 47). For the anti-nuclear movement in particular, see Heuser (1998); and Croft (2001b).

${ }^{14}$ Speech in Manchester on 4 July 1948, quoted in Edgerton (2018b, 82).

${ }^{15}$ See, inter alia, Holland (1991); Mangold (2002); Darwin (2009); Self (2010); Morris (2011); and Simms (2016). The argument is sometimes extended to defence policy as well (Baylis 1989; cf. Rees 2001).

${ }^{16}$ For examples, see Cain and Hopkins (2016); Wearing (2014, 2018).

${ }^{17}$ Introduced by Robinson and Gallagher, writing with Alice Denny, in 1961, the term "official mind" originally referred to the body of bureaucrats tasked with governing colonial affairs from London, but it has since been stretched to refer to the foreign and defence policy apparatus more broadly or even to a larger group of professionals sharing a common set of beliefs about said policy (Robinson, Gallagher, and Denny 1961; see also Heinlein 2002; Haseler 2007; Self 2010; Haseler 2012; Bevir and Daddow 2015). In general, the bureaucrats were less willing to cling to grandeur than were the politicians (Blackwell 1993, 25-7; Self 2010, 300). 
${ }^{18}$ Sanders and Houghton (2017, x). See also Mabon, Garnett, and Smith (2017, chap. 1). Some of these concepts now appear even in parliamentary documents on foreign policy (Gaskarth 2014, 42-3; Vucetic 2020b, 79-80).

${ }^{19}$ Quotes from Wallace $(1991,79,66,75,69)$. See also Wallace $(2000 ; 2005 a ; 2005 b)$. On

exceptionalism, see also Larsen (1997); Young (1998); Rees (2001); Baker (2002); Gamble (2003);

Marcussen et al. (1999); Grob-Fitzgibbon (2016); Sanders and Houghton (2017); Daddow (2011, 2015b, 2018); and Wellings (2019, esp. chap. 4).

${ }^{20}$ Note the semantics here: some argue the third "e" in Brexiteer was inserted strategically to invoke pride in the buccaneers and privateers of the sixteenth century, and their legendary "swashbuckling" endeavours (Ward and Rasch 2019, 3; see also Barnett 2018, chap. 13). On the historical constitution of Anglo-Saxons and Anglo-Saxonism, see, for example, Vucetic (2011b, chap. 2) and Shilliam (2018, chap. 3), and compare to Atlanticists and Atlanticism (Gamble 2003, 80-2; Dunne 2004).

${ }^{21}$ There are now hundreds of discrete studies of foreign policy that conceptualize nations as intersubjective social-cognitive structures that constitute the space where ideas, emotions, institutions, and practices intersect to affect collectively binding actions at the level of states, regions, and the international system as a whole (Vucetic 2017a, 2018). Constructivist IR, however, is similar but not identical to interpretivist British foreign policy scholarship (Bevir, Daddow, and Hall 2013; Bevir, Daddow, and Schnapper 2015; Daddow and Gaskarth 2011; Schnapper 2011; Gaskarth 2013; Edmunds, Gaskarth, and Porter 2014; Bevir and Daddow 2015).

${ }^{22}$ His context is Norman Tebbit's infamous "cricket test" (Ward 2004, 82-3, 115). Compare with Doty (1996b, 126). On the conflation of state and national identity in IR, see Berenskoetter $(2014,263)$.

${ }^{23}$ These are simplified definitions only: senso comune, or common sense, refers to the content of popular, everyday knowledge. Structures of feeling and habitus both refer to the broader intersubjective dispositions that produce common sense, whereby the former concept stresses the affective dispositions 
and the latter stresses the cognitive ones. Doxa refers to the unarticulated, taken-for-granted elements of common sense.

${ }^{24}$ For recent examples of Hallsian analyses of British life in history and sociology, see, respectively, Vernon (2017); and Valluvan (2019).

${ }^{25}$ Students of popular culture in IR and political geography see it the same way: masses routinely elaborate, negotiate, rework, or challenge elite positions. See, for example, Saunders and Strukov (2018), and compare with studies of British foreign policy that focus on liberal propaganda, capitalism, and/or the class system (e.g., Curtis 1995; Haseler 2012; Cain and Hopkins 2016; Wearing 2018).

${ }^{26}$ For a more sustained engagement with this large literature, including Jon Fox and Cynthia Miller-Idriss (2008), Michael Skey (2009) and others from a loosely Gramscian perspective, see Vucetic and Hopf (2020).

${ }^{27}$ Since the mid-2000s (e.g., Mitzen 2006), ontological security has become a workhorse for constructivist IR theorizing of the social-cognitive and emotional underpinnings of agents' motivation for action (Gaskarth 2013, 61-4).

${ }^{28}$ Neoclassical realism posits that all states seek survival because the international system is fundamentally anarchic, but it explains foreign policies by focusing on the interaction of (independent) systemic and (intervening) domestic-level variables such as, in this case, national identity.

${ }^{29}$ See Henderson, Wincott, and Jones (2017); Oliver (2018); Wellings (2019); and O'Toole (2018). For further context, See Kumar (2003); and Kenny (2014).

${ }^{30}$ This goes double for attempts to pursue clashing role orientations: "One cannot be an influential/rule of law state and at the same time seek to transgress international law in an opportunist-interventionist fashion" (Gaskarth 2014, 64).

${ }^{31}$ McCourt (2014a, 15). Elsewhere he has intimated that roles are at once situation-specific and sensitive to societal transformations (McCourt 2014b, 175). We could thus say that role theory sees foreign policy as a practice performed in and through joint actions involving Self-Other relations in multiple locales and 
at different scales, and not "just" at the intersection of the international and domestic environments. Space prevents me from engaging with this rich literature further, but see, inter alia, Hill (1979); Breuning (1995); Macleod (1997); MccGwire (2006); Gaskarth (2014, 2016); McCourt (2011); Morris (2011); Aggestam (2012); Daddow (2015a; 2019); Blagden (2019); Strong (2018); and Oppermann, Beasley, and Kaarbo (2019).

${ }^{32}$ Only Lecture 3, "The Atlantic Bridge," is available for listening: https://www.bbc.co.uk/programmes/p00hg2c7. On the significance of Franks, see Danchev (1993).

${ }^{33}$ Franks (1954). He likewise correctly dismissed isolationism as impossible (Gaskarth 2014, 48-51; Hill 2019, 8).

${ }^{34}$ Two additional points. First, like Doty, most interpretivists shy away from making causal claims (e.g., Hansen 2006, 22-5). But how questions are causal also depends on one's underlying theory of causation (compare, inter alia, Wendt 1999, 55-6, 87; Klotz 2008, 50-1; Navari 2008, 40-1; Kurki 2008, 184; Vucetic 2011a, 1307-11; McCourt 2014a, 46-53). Second, the "ideal type" interpretivist research design encompasses detailed accounts of how situated agents exert their agency (Bevir and Daddow 2015, 2813). This is beyond the scope of my study. And suffice it to say, the goal of the present approach to supplement, not supersede, other approaches (Humphreys 2015, 580).

${ }^{35}$ On elite-mass verticality, see Colley (2019, 4-5); Clarke et al. (2018, 6); and, more broadly, Hall (1996a); and Whitmeyer (2002).

${ }^{36}$ The project website is https://www.makingidentitycount.org. See also Hopf and Allan (2016).

${ }^{37}$ All supplementary files are available at https://www.makingidentitycount.org/united-kingdom (see, in particular, Vucetic, “A How-to Guide for Project Contributors,” December 2015; and Vucetic, “The United Kingdom, 1950-2000: Primary Texts,” 23 June 2016). On research design and methodological details, see Allan (2016); cf. Hansen (2006, chap. 5).

${ }^{38}$ Polities centred on Istanbul, Madrid, and Moscow come to mind. On British political development and Britishness, see, inter alia, Colley (2009 [1992]); Burton (1997); Paul (1997); Robbins (1998); Kumar 
(2003); Gamble (2003); Ward (2004); Darwin (2009); Barkawi and Brighton (2013); Kenny (2014);

Bhambra (2016); Vernon (2017); Shilliam (2018); and Wellings (2019).

${ }^{39}$ For an argument that a unifying, national, and mass democratic culture in the UK had already emerged in the $1930 \mathrm{~s}$ - thanks to the deep penetration of popular daily newspapers, the cinema, and other media infrastructures into daily life - see LeMahieu (1998). On the role of scholars, such as Richard Hoggart and Raymond Williams, and scholarly methods, such as Mass-Observation, see Savage (2010). ${ }^{40}$ Britishness is not the same as British citizenship (Croft 2012, 4; Doty 1996b, 130). While in 1948 the latter encompassed all subjects of the empire, in 1962, as we see in chapter 2, it came down to the territory of the UK and British Overseas Territories, plus the diaspora - British-born people living abroad. As for the national UK, Edgerton locates its decline in the 1970s, which witnessed the beginning of the internationalization of finance and production and the rise of subnational nationalism. To this we could also add the decline in political participation since the late 1980s.

${ }^{41}$ On mass media and Britishness, see LeMahieu (1988) and McClintock (1995). While weekly cinema audiences went down from around 26 million circa 1950 to around 14 million circa 1960, this was still about the same as the total circulation of all daily national newspapers and more than the total television program consumption figure. Note also that, in 1960, the BBC and ITV were each restricted to a sevenhour broadcasting day. For further details, see Appendix A; Webster $(2005,6)$; and Harrison $(2009,54-$ 8).

${ }^{42}$ Consider any number of James Bond films: in addition to looking at how camera angles and light illuminate, say, the portrait of the Queen, the coder must also pay attention to music, sound, and bodies, including the manner in which the protagonist touches objects and people (Funnell and Dodds 2017).

${ }^{43}$ British print media consumption likewise reflected and reproduced one's class and political identification. In Agatha Christie's Murder Is Announced, which is one of my sources in chapter 1, most characters seem to read more than one newspaper daily, in addition to the village newspaper and newsmagazines. Colonel Easterbrook reads the Times, the main establishment newspaper. The rich Miss 
Blacklock likes the conservative Daily Mail. The eccentric Miss Hinchcliffe and Miss Murgatroyd prefer the Liberal Party-leaning New Chronicle. Only the cranky (and wealthy) writer Edmund Swettenham reads the pro-communist Daily Worker.

${ }^{44}$ The analysts - none of whom resided in the UK at the time of research - were asked to tune out UK news (especially Brexit) and UK history (especially social and cultural [e.g., Spiering 2014]) until all coding and analysis was complete. My own researcher subjectivity reflections are in Vucetic (2017b). ${ }^{45}$ Together, Steps 3 and 4 could be dubbed “interpretive quantification” (Barkin and Sjoberg 2017). Compare Doty (1996a) and Hansen (2006).

${ }^{46}$ For summary tables as well as for lists of all counted identity categories with coding examples, see fulllength UK identity reports at the project website: https://www.makingidentitycount.org/united-kingdom. ${ }^{47}$ Scholars often lament the fact that no word but "British" exists to describe UK citizens as a group (e.g., Harrison 2010, xv). The term "British and Northern Irish" is merely a regional census category, whereas Tom Nairn's 1980s-vintage "Ukanians" has adherents only among the New Left.

${ }^{48}$ On eventfulness as a methodological technique, see Hansen (2006, 27-9); Skey (2009: 8, 117-9); and Guzzini (2012, 52-4). Compare to the concept of a dilemma (Bevir and Daddow 2015, 275, 280-1). ${ }^{49}$ Nearly fifty years after Churchill introduced this trope, Blair insisted that Britain was a "power that is at the crux of the alliances and international politics which shaped the world and its future" (quoted in Self 2002, 5). See also Kenny and Pearce (2018, 55-6); Sanders and Houghton (2017, 1-4); Simms (2016, 672); Gaskarth (2013, 66-68); Daddow and Gaskarth (2011, 13); Gamble (2003, 220); Reynolds (2000, chap. 8); Young (1998, 32-5); and Larsen (1997, 52).

${ }^{50}$ On paradigmatic cases, see Flybjerg $(2006,15-16)$. On case selection in constructivist IR, see Klotz (2008).

${ }^{51}$ A sample: Deighton (1990); Taylor (2016) [1991], chap. 4); Dell (1995); Clarke (2004 [1996]); Bell (1997); Young (1998); Peden (2012); Bevir, Daddow, and Schnapper (2015); Daddow (2015b); GrobFitzgibbon (2016); Smith (2017); and Hill (2019, chap. 2). 
${ }^{52}$ Even if we accept that audience effects are potentially present even in the most secretive policy arenas (e.g., Cormac and Aldrich 2018; Gun 2020), the fact remains that overt and covert foreign policy actions are qualitatively different (e.g., Heuser 1992; Cormac 2018), as are ("American," "Blairite") "sofa circle" discussions in comparison to parliamentary debates or white papers in comparison to cabinet-level memos (e.g., Wallace 1975; Gaskarth 2013). 
Figure 1. Discourse Analysis: From Texts to Topography

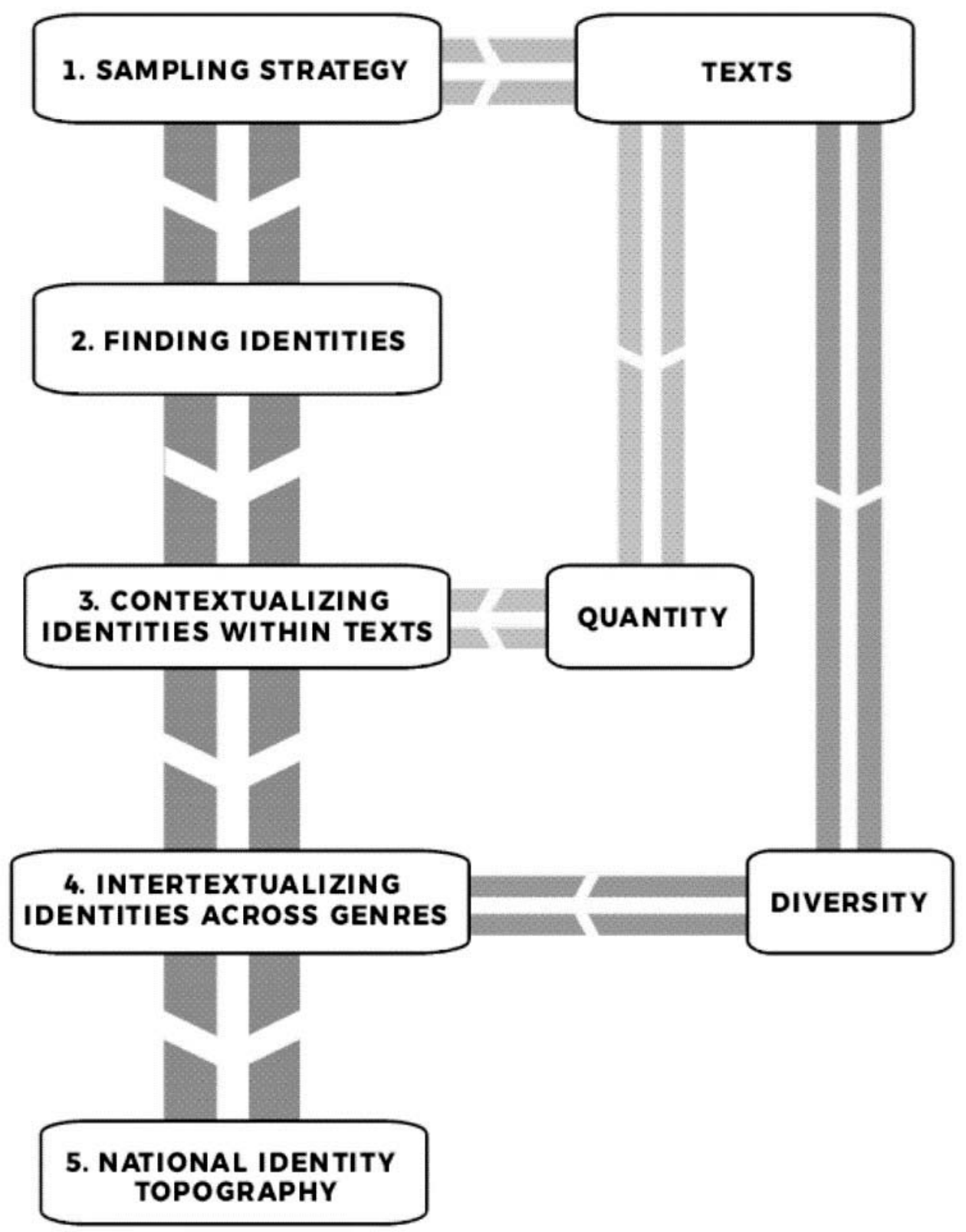




\begin{tabular}{|c|c|c|c|c|c|}
\hline Year & Speeches & Newspapers & Textbooks & Films & Novels \\
\hline \multirow[t]{2}{*}{$\begin{array}{l}1950 \\
\text { (Lab) }\end{array}$} & $\begin{array}{l}\text { Attlee. King's Speech, } \\
\text { 1.3. }\end{array}$ & Daily Express & Carter \& Mears. History of Britain. & The Blue Lamp & Christie. A Murder Is Announced \\
\hline & $\begin{array}{l}\text { Attlee. Margate, } \\
3.10 .\end{array}$ & Daily Mirror & Rayner. Short History of Britain & $\begin{array}{l}\text { What the Butler } \\
\text { Saw }\end{array}$ & Shute. A Town Like Alice \\
\hline \multirow[t]{2}{*}{$\begin{array}{l}1960 \\
\text { (Cons) }\end{array}$} & $\begin{array}{l}\text { Macmillan. Scarborough, } \\
15.10 .\end{array}$ & Daily Express & $\begin{array}{l}\text { Barker \& Ollard. General History of } \\
\text { England }\end{array}$ & Doctor in Love & Fleming. $\operatorname{Dr}$ No \\
\hline & $\begin{array}{l}\text { Macmillan. Queen's } \\
\text { Speech, 1. } 11 .\end{array}$ & Daily Mirror & Strong. History of Britain and the World & $\begin{array}{l}\text { Sink the } \\
\text { Bismarck! }\end{array}$ & Christie. 4.50 from Paddington \\
\hline \multirow[t]{2}{*}{$\begin{array}{l}1970 \\
\text { (both) }\end{array}$} & $\begin{array}{l}\text { Wilson. HC Deb on } \\
\text { Address } 2.6\end{array}$ & Daily Express & Titley. Machines, Money and Men & $\begin{array}{l}\text { On Her Majesty's } \\
\text { Secret Service }\end{array}$ & Christie. Endless Night \\
\hline & $\begin{array}{l}\text { Heath. HC Deb on Add. } \\
\text { 2.6. }\end{array}$ & Daily Mirror & Larkin. English History & Battle of Britain & MacLean. Force 10 from Navarone \\
\hline \multirow[t]{2}{*}{$\begin{array}{l}1980 \\
\text { (Cons) }\end{array}$} & $\begin{array}{l}\text { Thatcher. Brighton. } \\
10.10 .\end{array}$ & Daily Express & $\begin{array}{l}\text { Hill. British Economic and Social History } \\
1700-1975\end{array}$ & Life of Brian & Forsyth. The Devil's Alternative \\
\hline & $\begin{array}{l}\text { Queen's Speech. } \\
7.11 .\end{array}$ & Daily Mirror & Sked \& Cook. Post-War Britain & McVicar & Smith. Wild Justice \\
\hline \multirow[t]{2}{*}{$\begin{array}{l}1990 \\
\text { (Cons) }\end{array}$} & $\begin{array}{l}\text { Queen's Speech. } \\
\text { 7. } 11 .\end{array}$ & The Sun & Kavanagh \& Morris. Consensus Politics & Shirley Valentine & Forsyth. The Negotiator \\
\hline & $\begin{array}{l}\text { Major. 'First Speech', } \\
\text { 4. } 12 .\end{array}$ & Daily Mirror & $\begin{array}{l}\text { Connolly \& Barry. Britain 1900-1939 \& } \\
\text { May. Economic and Social History }\end{array}$ & The Krays & Smith. A Time to Die \\
\hline \multirow[t]{2}{*}{$\begin{array}{l}2000 \\
(L a b)\end{array}$} & $\begin{array}{l}\text { Blair. Brighton. } \\
26.9 .\end{array}$ & The Sun & Walsh. Modern World History. & Chicken Run & $\begin{array}{l}\text { Rowling. Harry Potter and the Goblet } \\
\text { of Fire }\end{array}$ \\
\hline & $\begin{array}{l}\text { Blair. 'Britain speech' } \\
\text { 28. } 3 .\end{array}$ & Daily Mail & $\begin{array}{l}\text { Culpin \& Turner. Making Modern } \\
\text { Britain }\end{array}$ & Gladiator & $\begin{array}{l}\text { Rowling. Harry Potter and the } \\
\text { Philosopher's Stone }\end{array}$ \\
\hline \multicolumn{6}{|c|}{$\begin{array}{l}\text { NOTES: Coding was done from June } 2015 \text { to December 2017. For more on source selections, including complete bibliography, see Appendix A. For complete } \\
\text { reports, detailed coding guidelines and coding examples, and other supplementary files, go to the project website https://www.makingidentitycount.org/ } \\
\text { The reports for 1980, 1990, and } 2000 \text { are co-authorships with, respectively, David Orr, Kristen M. Olver and Alyssa Maraj Grahame. Kazim Rizvi, Melanie } \\
\text { Mitchell and Kalathmika Natarajan provided invaluable research assistance in identifying and collecting historical materials. }\end{array}$} \\
\hline
\end{tabular}


Table 2 Parliaments, governments, prime ministers, foreign ministers \& events, $\mathbf{1 9 5 0 - 2 0 0 0}$

\begin{tabular}{|c|c|c|c|c|c|}
\hline \multirow{3}{*}{\begin{tabular}{|l} 
Parliament \\
1950
\end{tabular}} & \multirow{3}{*}{\begin{tabular}{|l} 
Gov't \\
Labour
\end{tabular}} & \multirow{3}{*}{\begin{tabular}{|l} 
Prime Minister \\
Clement Attlee
\end{tabular}} & Foreign Minister* & \multicolumn{2}{|c|}{ Events (incl. Defence Reviews) } \\
\hline & & & Ernest Bevin & \multirow{5}{*}{$\begin{array}{l}1950 \text { s } \\
\text { Korea } \\
\text { Suez Crisis } \\
\text { Schuman \& Pleven }\end{array}$} & \multirow{5}{*}{ Sandys (1957) } \\
\hline & & & Herbert Morrison & & \\
\hline 1951 & \multirow[t]{5}{*}{ Cons. } & Winston Churchill & Sir Anthony Eden & & \\
\hline \multirow[t]{3}{*}{1955} & & \multirow[t]{2}{*}{ Anthony Eden } & Harold Macmillan & & \\
\hline & & & \multirow[t]{2}{*}{ Selwyn Lloyd } & & \\
\hline & & \multirow[t]{2}{*}{1957 Harold Macmillan } & & \multirow{5}{*}{$\begin{array}{l}\text { 1960s } \\
\text { Winds of Change } \\
\text { Skybolt Affair } \\
\text { De Gaulle veto }\end{array}$} & \multirow{5}{*}{ Healey (1966) } \\
\hline 1959 & & & Alec Douglas-Home & & \\
\hline \multirow[t]{2}{*}{1964} & \multirow[t]{4}{*}{ Labour } & 1963 Sir Douglas-Home & Richard Austen Butler & & \\
\hline & & \multirow[t]{4}{*}{ Harold Wilson } & Patrick Gordon Walker & & \\
\hline \multirow[t]{2}{*}{1966} & & & Michael Stewart & & \\
\hline & & & George Brown & \multirow{5}{*}{$\begin{array}{l}1970 \text { s } \\
\text { East of Suez } \\
\text { Nixon Shocks } \\
\text { EC Entry }\end{array}$} & \multirow{5}{*}{ Mason (1975) } \\
\hline \multirow[t]{2}{*}{1970} & \multirow[t]{2}{*}{ Cons. } & & Michael Stewart & & \\
\hline & & Edward Heath & Sir Alec Douglas-Home & & \\
\hline 1974 & Labour** & Harold Wilson & James Callaghan & & \\
\hline \multirow[t]{2}{*}{1979} & \multirow[t]{8}{*}{ Cons. } & \multirow[t]{2}{*}{1976 James Callaghan } & Anthony Crosland & & \\
\hline & & & David Owen & \multirow{5}{*}{$\begin{array}{l}\text { 1980s } \\
\text { Falkands Islands } \\
\text { Trident purchase } \\
\text { Thatcher's rebate }\end{array}$} & \multirow{5}{*}{ Nott (1981) } \\
\hline 1983 & & \multirow[t]{4}{*}{ Margaret Tharcher } & Baron Carrington & & \\
\hline & & & Francis Pym & & \\
\hline \multirow[t]{3}{*}{1987} & & & Sir Geoffrey Howe & & \\
\hline & & & John Major & & \\
\hline & & \multirow[t]{2}{*}{1990 John Major } & Douglas Hurd & \multirow{2}{*}{$\begin{array}{l}\text { 1990s } \\
\text { Gulf War } \\
\text { Bosnia } \\
\text { Maastricht }\end{array}$} & \multirow[b]{2}{*}{$\begin{array}{l}\text { King (1990) } \\
\text { Rifkind (1994) }\end{array}$} \\
\hline 1992 & & & Malcolm Rifkind & & \\
\hline \multirow{5}{*}{$\begin{array}{l}1997 \\
2001\end{array}$} & Labour & Tony Blair & Robin Cook & $2000 \mathrm{~s}$ & \\
\hline & & & Jack Straw & Iraq & \\
\hline & & & & War on Terror & Hoon (2002) \\
\hline & & & & The euro & Hoon (2003) \\
\hline & & & Margaret Beckett & & \\
\hline
\end{tabular}




\section{Appendix A}

\section{Archive}

Given that ethnography is limited to the present and the immediate past, the most valuable interpretivist methodology for reconstructing postwar Britishness is an inductively oriented discourse analysis. Assembling an archive or corpus for such analysis can be a challenging task in that there seems to be both a huge number of possible texts from which national identity categories can be recovered and an abundance of different, often conflicting, texts about what counts as elite versus mass discourse in a given historical period. This selection strategy follows the theoretical and methodological rationale set out in the Making Identity Count project https://www.makingidentitycount.org/.

\section{Leadership speeches}

Our aim was to select two speeches that were at once high circulating, regular ("annual"), and on "anything but national identity" (nothing on devolution or "The Future of Britishness," for example). The prime minister's statements in the "State Opening of Parliament," a new session of Parliament, and the "annual party conference speech" met these criteria. With respect to the first, the UK government's legislative program (a.k.a. the ministerial agenda) for the forthcoming parliamentary session is traditionally laid out in the Queen's Speech (in 1950, it was the King's Speech), a.k.a. the "Most Gracious Speech from the Throne." Set in 1852, the ceremony is part of the UK's "unwritten" constitution, which relies heavily on understandings and assumptions more than on hard rules. The Queen's Speech is prepared by the Prime Minister's Office, and the monarch reads it as a matter of her constitutional duty. In the period under study, the combination of the royal pomp and disclosure of the upcoming policies and pieces of legislation 
by the government naturally attracted significant media attention, including a live television audience.

Party conferences in the UK serve to rally their constituencies, gain a few days of newspaper headlines, and raise money. They also normally take place in early fall and away from the capital city - in Birmingham or Brighton, for example. They have also evolved over time, with latter years witnessing the emergence of workshops, book fairs, movie screenings, and other events within them. In the immediate postwar decades, the party conference was a site of policy-making; from about 1980 onwards, it became an opportunity for image-making. The prime minister's speech was always the central event, however.

We departed from this rule thrice. In 1970, the UK had a change of government and we decided to have one leadership speech from each the two prime ministers that year: the outgoing Wilson (Labour) and the incoming Heath (Conservative). We selected the speeches the two leaders gave in the post-election State Opening on 2 July. Both speeches were given during the "Debate on the Address," a.k.a. "Loyal Address," which is occurs when members of both houses debate the content of the speech (an "Address in Reply to Her Majesty's Gracious Speech") another long-standing parliamentary ritual.

In the year 1990 the UK again had two prime ministers: Margaret Thatcher resigned on 22 November. The subsequent leadership contest within the Conservative Party was carried by John Major, chancellor of the exchequer, who then became the nation's leader on 28 November 1990. His speech at the Queen Elizabeth II Conference Centre on 4 December 1990 was his first as prime minister. 
In 2000, we selected Tony Blair's “Britain Speech” on 28 March, rather than the Queen's Speech or his statement in the Debate on the Address on 6 December. This was done to reflect the changing nature of mass mediation of leadership speeches in the internet age and because of the fact that this speech had been widely received as "the" statement of "Blairism" and Blair's attempt to "rebrand" the UK.

\section{Newspapers}

We followed the rankings based on the Press Council and Audit Bureau of Circulations circulation figures or the closest equivalent. Accordingly, we selected the Daily Express and the Daily Mirror from 1950 through 1980, the Sun and the Daily Mirror for 1990, and the Sun and the Daily Mail for 2000. Although in national circulation numbers the Sun had already overtaken the Daily Express in 1980, we continued to use the latter due to some difficulties in gaining access to the former's archive. With this selection, we achieved some variance in the ownership structures and ideological orientations of newspapers known as "popular" or "mass-market" (a.k.a. "red-tops" or "tabloids"). We sampled the editions published on the fifteenth day of each month, including, when appropriate, Sunday equivalents of the selected newspaper (the Sunday Mirror, the Sunday Express, the Mail on Sunday but not the News of the World). ${ }^{1}$

\section{History textbooks}

For each year under study we selected the two high school-level publications on modern English or British history that were most likely to have been used at the time in private and state schools in the UK, primarily in England. To that end, we reviewed the histories and institutional contexts of the educational program in history in England and then combed contemporary and historical 
reviews and discussions in the journals Teaching History and History of Education Review. While it is true that UK history teachers began to use textbooks in their classrooms only following the introduction of the history General Certificate of Education Exam (GCSE) and the National Curriculum initiative in the late 1980s, it is still the case that numerous textbooks - and "topic-books" - existed and circulated throughout the period under study. Whenever appropriate, we used publications catering to students between the ages of fourteen and nineteen, particularly those studying for history GCSE and history A Level exams (the more advanced qualifications generally required for university entrance) or their closest historical equivalents (CSE/O-Level). Next, for ample reflection we looked at "the last hundred years," whatever the type of history (economic, social, cultural, political etc.), as well as at "recent editions" - that is, editions published in the beginning of the year or in the preceding year or two - 1958 or 1959 for 1960, for example. If one of the two textbooks we selected covered only a short period of history and/or was exceptionally short, we added a third textbook to our sample. ${ }^{2}$

Novels

Identifying "bestselling novels" was challenging. To select two top-selling items on the consumer market of books, bought by private individuals for their own use or as gifts, in each year, we first consulted scholarly histories of the book and of the UK fiction industry. For 1950 and 1960, we consulted annual round-ups of the bestseller market produced by W.H. Smith's Trade News, the Observer, the Bookseller, the Evening Standard, the Evening News, Time and Tide, the Sunday Telegraph, and the Daily Express and picked the two British-authored novels closest to the top of each list. ${ }^{3}$ For 1970 and 1980, the reliability of bestseller lists improved thanks to the introduction of surveys, automated data collection (after 1980), and other ranking 
instruments. Especially helpful were secondary assessments of said lists published in specialist magazines such as the Listener, a weekly BBC magazine published until 1991, and by journalist Alex Hamilton in the Guardian (from 1970 onwards). For 1990 and 2000, we followed the rankings generated by computerized data capture via Electronic Point-of-Sale equipment and disseminated by companies such as Nielsen BookScan. As Table I.1 in the introduction shows, several authors appear in multiple years: Fleming, Christie, Smith, Forsyth, and Rowling. ${ }^{4}$

The paperback revolution changed our selection criteria as well since it rendered paperback the dominant format for bestsellers. First, the paperback revolution changed the meaning of high-circulating: in the late 1940s, a top hardback novel would achieve sales of 100,000 over several years, whereas in the 1990s a bestselling paperback would have 500,000 copies sold in weeks. Second, this means that some our "bestselling novels of the year" after 1960 were in fact paperback editions of a hardback released a year, or two or three, before the year of the study. In 1960, we thus selected Ian Fleming's Dr No, released in March 1958 over Fleming's For Your Eyes Only, released in April 1960. In principle, either one would have been acceptable as UK readers en masse were enjoying multiple of Fleming's Bond novels. However, $\operatorname{Dr} N o$, the sixth book in the espionage adventure series, topped that year's bestseller with more than 150,000 copies sold thanks to the paperback release in February as well as, to a lesser extent, to both text and comic-strip serializations occurring that year in the Daily Express. For Your Eyes Only, in contrast, was released in hardback and sold fewer than 22,000 copies. ${ }^{5}$ The same rationale applied to 4.50 from Paddington, a novel by Agatha Christie first published in November 1957 but appearing in paperback three years later with Fontana Books. ${ }^{6}$

Movies 
To select top watched movies by UK directors we followed two strategies. For the 1950 to 1980 period, we referred to the end-of-the-year movie reports published in the Times. Based on the annual surveys of box-office returns (including both "general release" and "reserved tickets") collected and analyzed by the industry publication Motion Picture Herald, these reports do not provide details such as the numbers of viewers, but they helpfully identify and sometimes rankorder most watched movies in the UK.

For 1990 and 2000, we used the box-office data reported in the histories of British film the British Film Institute's BFI Film and Television Handbook above all. In the case of a tie, we went for the more British of the two. For 1980, for example, we selected McVicar over Yanks because the former was a UK production and the latter a UK-US production. In 2000, in contrast, we went for the greater box-office popularity of Gladiator, a sword-and-sandal drama directed by a British filmmaker and delivered in British accents, over Billy Elliot, an identity-rich story of a coal miner's son in Northern England who takes up ballet. ${ }^{7}$ Film histories likewise helped determine release dates. Whenever we encountered a reasonable rankings tie, we selected the more recent release: McVicar, released in August 1980, over Yanks, released in September 1979, for example. For the earlier years, however, we acknowledged that movies released in the previous year often topped most watched estimates in the following year. In the 1950s, for instance, showings of popular movies in some cases went on for eighteen consecutive months. 


\section{Notes}

${ }^{1}$ For further details, see Srdjan Vucetic, "The United Kingdom, 1950-2000-Primary Texts," 23 June 2016. Available at https://srdjanvucetic.wordpress.com/research/id/srdj-postwar-uk-sources-final/. We assumed letters to editors to be genuine.

${ }^{2}$ Connolly and Phillips (1989), for example. For further details, see Vucetic (2020a).

${ }^{3}$ British interest in translated fiction was, in any case, low throughout.

${ }^{4}$ For advice, I am grateful to Professor Shafquat Towheed, director of the Book History Research Group and the UK Reading Experience Database, the Open University.

${ }^{5}$ This is based on Bennett and Woollacott $(1987,26)$ and Benson $(2015,17)$. Analyses of Bond as a nationalist, antideclinist fantasy are of course plentiful (e.g., Buettner 2016; Funnell and Dodds 2017). We relied on our own coding.

${ }^{6}$ Neither is to be confused with "the steady longterm sellers" such as the Bible, Tolkien's three-volume fantasy The Lord of the Rings (1954-55), and, arguably, George Orwell's Animal Farm (1945). In all cases we selected novels dealing with contemporary themes. To go with the year 1960 again, we were initially drawn to Lady Chatterley's Lover by D.H. Lawrence, a book that sold over 200,000 paperback copies within weeks following the infamous obscenity trial in November-October of that year. However, this was a Penguin paperback of a book published in 1928. Our runners-up included John Braine's Room at the Top (1957), which sold well thanks to a lucrative paperback-movie tie-in in 1959; David Storey's This Sporting Life, which won the 1960 Macmillan Fiction Award; and Nevil Shute's On the Beach, a novel first published in 1957 that sold well in the tens of thousands due to the author's death in 1960 and the story's cinamatization in 1959, but without quite reaching the numbers of the Fleming and Christie books.

${ }^{7}$ On why Gladiator is a British and not merely "another Hollywood movie," see Dalby $(2008,443)$. 


\section{Appendix B}

\section{Events}

The rationale for finding events is set out in the introduction of the book.

Figure B.1: Selecting Events

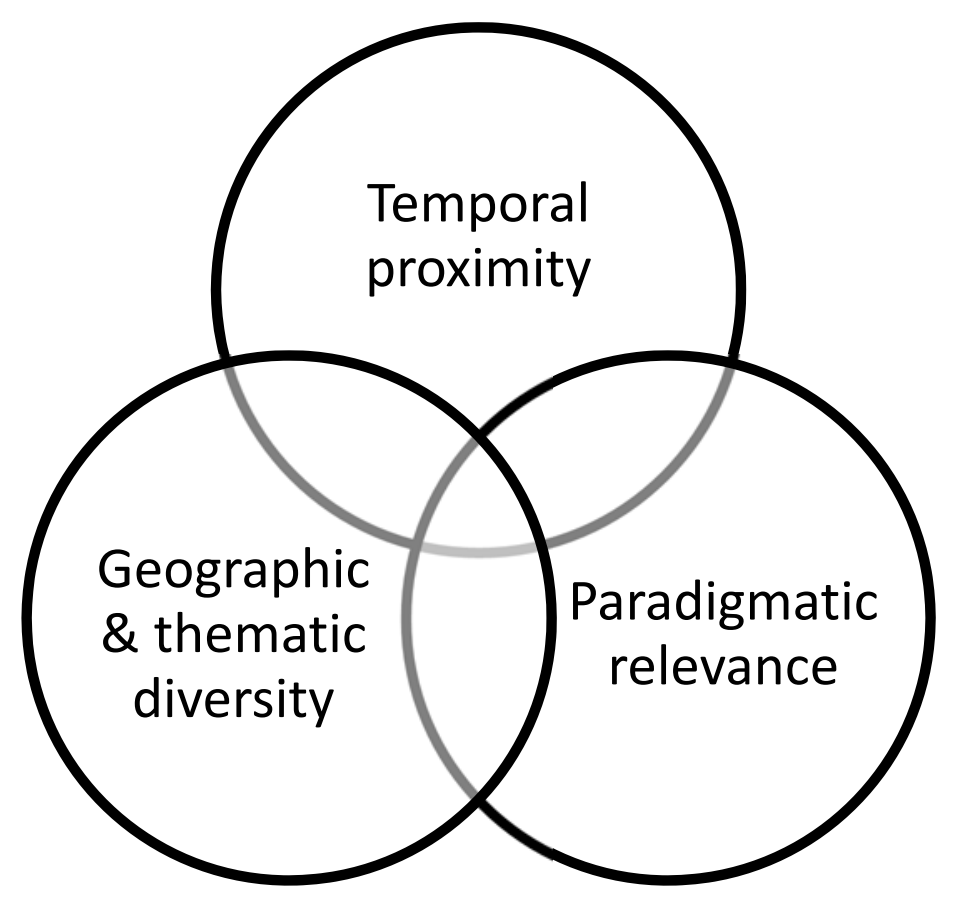

UK Defence Reviews, 1957-2003

Sandys, D. 1957. Statement on Defence, 1957. London: Ministry of Defence.

http://filestore.nationalarchives.gov.uk/pdfs/small/cab-129-86-c-57-69-19.pdf.

Healey, D. 1966. Defence Review: The Statement on the Defence Estimates. London: Ministry of

Defence. http://filestore.nationalarchives.gov.uk/pdfs/small/cab-129-124-c-33.pdf. 
Mason, R. 1975. Statement on the Defence Estimates London: Ministry of Defence.

http://filestore.nationalarchives.gov.uk/pdfs/small/cab-129-181-c-21.pdf.

Nott, J. 1981. The United Kingdom Defence Programme: The Way Forward. London: Ministry of Defence. http://fc95d419f4478b3b6e5f-

3f71d0fe2b653c4f00f32175760e96e7.r87.cf1.rackcdn.com/991284B4011C44C9AEB423DA04 A7D54B.pdf.

King, T. 1990. Defence (Options for Change). London: Ministry of Defence.

https://api.parliament.uk/historic-hansard/commons/1990/jul/25/defence-options-for-change.

Rifkind, M. 1994. Front Line First. London: Ministry of Defence.

https://publications.parliament.uk/pa/cm199394/cmhansrd/1994-07-14/Debate-1.html.

Hoon, G. 2002. The Strategic Defence Review: A New Chapter. London: Ministry of Defence.

http://webarchive.nationalarchives.gov.uk/20090805012836/http://www.mod.uk/DefenceInternet /AboutDefence/CorporatePublications/PolicyStrategyandPlanning/StrategicDefenceReviewANe wChaptercm5566.htm.

Hoon, G. 2003. Delivering Security in a Changing World: Defence White Paper. London: Ministry of Defence.

http://webarchive.nationalarchives.gov.uk/20121018172935/http://www.mod.uk/NR/rdonlyres/0 51AF365-0A97-4550-99C0-4D87D7C95DED/0/cm6041I_whitepaper2003.pdf. 


\title{
References
}

\section{Primary Sources}

\section{Speeches}

British Political Speech, online archive, http://www.britishpoliticalspeech.org/.

The Official Report (Hansard), https://hansard.parliament.uk/.

\author{
Newspapers \\ Daily Mirror \\ Daily Express
}

Daily Mail

Sun

\section{Textbooks}

Barker, William Alan, G.R.St Aubyn, and Richard Lawrence Ollard. 1960. A General History of England, 1832-1960. 2nd ed. London: A \& C Black.

Carter, .H., and R.A.F. Mears. 1948. A History of Britain, 1876-1953. 2nd ed. Oxford:

Clarendon Press, 
Connolly, P., and Barry Phillips. 1989. Britain, 1900-1939. Southwick: Spartacus Educational Publishers.

Culpin, C., and Brian Turner. 1997. Making Modern Britain: British Social and Economic History from the 18th century to the Present Day. London: Collins Educational.

Hill, C.P. 1977. British Economic and Social History, $1700-1975,4^{\text {th }}$ ed. London: Edward Arnold.

Kavanagh, Dennis, and Peter Morris. 1989. Consensus Politics from Attlee to Thatcher. 1st ed. Oxford: Basil Blackwell.

Larkin, Patrick John. 1964. English History for Certificate Classes, 1789-1939. London: Hulton Educational Publications.

May, Trevor. 1987. An Economic and Social History of Britain, 1760-1970. 1st ed. Harlow: Longman.

Rayner, R. 1948. A Short History of Britain. Harlow: Longman.

Sked, Alex, and Chris Cook. 1979. Post-War Britain: A Political History, 1st ed. Sussex: The Harvester Press.

Strong, Charles Frederick. 1956. History of Britain and the World, Book Five: The Twentieth Century and the Contemporary World. 2nd ed. [S.I.], London: U.L.P. 
Titley, D.P. 1969. Machines, Money and Men. Economic and Social History of Great Britain, 1700-1960's. London: Blonde Educational.

Walsh, Ben. 1996. GCSE Modern World History. 1st ed. London: John Murray Pubs Ltd.

\section{Novels}

Christie, Agatha. 1960. 4.50 from Paddington. London: Fontana, paperback.

-. 1967. Endless Night. London: Collins Crime Club, paperback.

-. 2007. A Murder Is Announced. New York: Harper (originally: London: Collins Crime Club, 1950).

Fleming, Ian. 1960. Dr No. London: Pan Books, paperback.

Forsyth, Frederick. 1979. The Devil's Alternate London: Hutchinson.

-. 1989. The Negotiator. London: Bantam Press.

MacLean, Alistair. 1968. Force 10 from Navarone. London: Collins Crime Club, paperback.

Rowling, J.K. 1997.Harry Potter and the Philosopher's Stone, London: Bloomsbury.

-. 2000. Harry Potter and the Goblet of Fire. London: Bloomsbury.

Shute, Nevil. 1971. A Town Like Alice. London: Heinemann, (originally: London: Heinemann, 1950). 
Smith, Wilbur. 1979. Wild Justice. London: Heinemann.

-. 1989. A Time to Die. London: Heinemann.

\section{Movies}

Battle for Britain (dir. Guy Hamilton), 1970.

Chicken Run (dir. Peter Lord and Nick Park), 2000.

Doctor in Love (dir. Ralph Thomas), 1960.

Gladiator (dir. Ridley Scott), 2000.

Life of Brian (dir. Terry Jones), 1980.

McVicar (dir. Tom Clegg), 1980.

On Her Majesty's Secret Service (dir. Peter R. Hunt), 1970.

Sink the Bismarck! (dir. Lewis Gilbert), 1960.

Shirley Valentine (dir. Lewis Gilbert), 1990.

The Blue Lamp (dir. Basil Dearden), 1950.

The Krays (dir. Peter Medak), 1990.

What the Butler Saw (dir. Godfrey Grayson), 1950. 


\section{References}

Abrahamsen, Rita, Jean-François Drolet, Alexandra Gheciu, Karin Narita, Srdjan Vucetic, and Michael C. Williams. 2020. "Confronting the International Political Sociology of the New Right." Collective Discussion. International Political Sociology 14 (1): 94-107.

Adamthwaite, Anthony. 1985. "Britain and the World, 1945-9: The View from the Foreign Office.” International Affairs 61 (2): 223-35.

Aggestam Lisbeth. 2012. European Foreign Policy and the Quest for a Global Role: Britain, France and Germany. London: Routledge.

Aldrich, Richard J. 2001. The Hidden Hand: Britain, America and Cold War Secret Intelligence. London: John Murray Publishers.

Allan, Bentley. 2016. “A Method for Uncovering National Identity.” In Making Identity Count: Building a National Identity Database, ed. Ted Hopf and Bentley Allan, 20-48. Oxford: Oxford University Press.

Allan, Bentley, Srdjan Vucetic, and Ted Hopf. 2018.“The Distribution of Identity and the Future of International Order: China's Hegemonic Prospects.” International Organization 72 (4): 839-69.

Ashton, S.R. 2007. "British Government Perspectives on the Commonwealth, 1964-71: An Asset or a Liability?" Journal of Imperial and Commonwealth History 35 (1): 73-94.

Aulich, James, ed. 1992. Framing the Falklands War: Nationhood, Culture and Identity. Milton Keynes: Open University Press.

Babic, M. 2020. "Let's Talk about the Interregnum: Gramsci and the Crisis of the Liberal World Order.” International Affairs. https://doi.org/10.1093/ia/iiz254.

Ball, Simon J. 1996. "Macmillan and British Defence Policy." In Harold Macmillan and 
Britain's World Role, ed. Richard Aldous and Sabine Lee, 67-96. London: Palgrave Macmillan.

Bell, Duncan. 2019. “Anglospheres: Empire Redivivus?” In The Anglosphere: Continuity, Dissonance, Location, ed. Ben Wellings and Andrew Mycock, 38-55. Oxford: Oxford University Press.

Bell, Duncan, and S. Vucetic. 2019. "Brexit, CANZUK, and the Legacy of Empire." British Journal of Politics and International Relations 21 (2): 367-82.

Bailkin, Jordanna. 2012. The Afterlife of Empire. Berkeley: University of California Press.

Barkawi, Tarak, and Shane Brighton. 2013. "Brown Britain: Post-Colonial Politics and Grand Strategy." International Affairs 89 (5): 1109-23.

Baker, David. 2002. "Elite Discourse and Popular Opinion on European Union: British Exceptionalism Revisited.” Politique Européenne 2 (6): 18-35.

Barker, Elisabeth. 1983. The British between the Superpowers, 1945-50. London: Macmillan.

Barkin, J. Samuel, and Laura Sjoberg, eds. 2017. Interpretive Quantification: Methodological Explorations for Critical and Constructivist IR. Ann Arbor: University of Michigan Press.

Barnett, Anthony. 1982. Iron Britannia. London: Busby.

-. 2017. The Lure of Greatness. London: Unbound.

Barnett, Correlli. 1972. The Collapse of British Power. London: Methune.

Basham, Victoria M. 2018. "Liberal Militarism as Insecurity, Desire and Ambivalence: Gender, Race and the Everyday Geopolitics of War." Security Dialogue 49 (1-2): 32-43.

Baylis, John. 1989. British Defence Policy: Striking the Right Balance. Basingstoke: Macmillan. 
Baylis, John, and Alan Macmillan. 1993. "The British Global Strategy paper of 1952.” Journal of Strategic Studies 16 (2): 200-26.

Baylis, John, and Kristan Stoddart. 2015. The British Nuclear Experience: The Roles of Beliefs, Culture, and Identity. Oxford: Oxford University Press.

Bayram, Burcu, and Vivian Ta. 2019. "Measuring Common Knowledge: Latent Semantic Analysis, Linguistic Synchrony, and Common Knowledge in International Relations." Sage Journals (International Relations), 8 September 2019, 1-24.

Beaumont, Paul. 2014. "Performing Nuclear Peace: How Nuclear Weapons Have Kept Britain Great from Thatcher to Blair.” Master's thesis, Norwegian University of Life Sciences.

-. 2017. "Brexit, Retrotopia and the Perils of Post-Colonial Delusions." Global Affairs 3 (4-5): $379-90$.

Beck, Peter J., 2009. “'The Less Said about Suez the Better': British Governments and the Politics of Suez's History, 1956-67.” English Historical Review 124 (508): 605-40.

Bell, Duncan. 2007. The Idea of Greater Britain: Empire and the Future of World Order, 18601900. Princeton: Princeton University Press.

-. and Srdjan Vucetic, 2019, "Brexit, CANZUK, and the Legacy of Empire." British Journal of Politics and International Relations 21 (2): 367-82.

Bell, P.M.H. 1997. France and Britain, 1940-1994: The Long Separation. London: Longman. Bennett, Tony, and Janet Woollacott. 1987. Bond and Beyond: The Political Career of a Popular Hero. London: Macmillan Education.

Benson, Raymond. 2015. The James Bond Bedside Companion. London: Crossroad Press. Berenskoetter, Felix. 2014. "Parameters of a National Biography." European Journal of International Relations 20 (1): 262-88. 
Bevir, Mark, and Oliver Daddow. 2015. "Interpreting Foreign Policy: National, Comparative and Regional Studies.” International Relations 29 (3): 273-87.

Bevir, Mark, Oliver Daddow, and Ian Hall. 2013. "Introduction: Interpreting British Foreign Policy.” British Journal of Politics and International Relations 15, 2: 163-74.

Bevir, Mark, Oliver Daddow, and Pauline Schnapper. 2015. "Introduction: Interpreting British European Policy." Journal of Common Market Studies 53 (1): 1-17.

Bew, John. 2016. Citizen Clem: A Biography of Attlee, Winner of the Orwell Prize. London: Hachette UK.

Bhambra, Gurminder K. 2016. "Viewpoint: Brexit, Class and British 'National' Identity." Discover Society. https://discoversociety.org/2016/07/05/viewpoint-brexit-class-and$\underline{\text { british-national-identity/ }}$

Billig, Michael. 1995. Banal Nationalism. London: Sage.

Blackwell, Michael. 1993. Clinging to Grandeur: British Attitudes and Foreign Policy in the Aftermath of the Second World War. Westport, CT: Greenwood Press.

Blagden, David. 2019. “Two Visions of Greatness: Roleplay and Realpolitik in UK Strategic Posture.” Foreign Policy Analysis 15 (4): 470-91.

Boffey, Daniel. "Brexit broadside: British Officials Bristle at Danish Scorn.” Guardian, 14 June 2017. https:/www.theguardian.com/politics/2017/jun/14/road-to-brexit-is-paved-withamusement-danish-and-brave-faces-british.

Breuning, Marijke. 1995. "Words and Deeds: Foreign Assistance Rhetoric and Policy Behavior in the Netherlands, Belgium, and the United Kingdom." International Studies Quarterly 39 (2): 235-54. 
Brown, Gordon. 2004. Speech by the Rt Hon Gordon Brown MP, Chancellor of the Exchequer, at the British Council annual lecture, July 7. On file with the author.

Browning, Christopher S. 2018. "Brexit, Existential Anxiety and Ontological (In)security." European Security 27 (3): 336-55.

Buettner, Elizabeth. 2016. Europe after Empire: Decolonisation, Society, and Culture. Cambridge: Cambridge University Press.

Burkett, Jodi. 2013. Constructing Post-Imperial Britain: Britishness, "Race” and the Radical Left in the 1960s. London: Palgrave.

Burton, Antoinette. 1997. "Who Needs the Nation? Interrogating 'British' History.” Journal of Historical Sociology 10 (3): 227-48.

Cain, P.J., and A.G. Hopkins. 2016. British Imperialism, 1688-2000, $3^{\text {rd }}$ ed. London: Routledge.

Campbell, Duncan. 1986. The Unsinkable Aircraft Carrier: American Military Power in Britain. London: Michael Joseph.

Chalmers, Malcolm. 1985. Paying for Defence Military Spending and British Decline. London: Pluto Press.

Chandler, David. 2003. "Rhetoric without Responsibility: The Attraction of 'Ethical' Foreign Policy." British Journal of Politics and International Relations 5 (3): 295-316.

Charmley, John. 1995. Churchill's Grand Alliance: The Anglo-American Special Relationship, 1940-57. New York: Harcourt Brace.

Clarke, Peter. 2004 [1996]. Hope and Glory: Britain 1900-1990: London: Penguin Press.

Clarke, Nick, Will Jennings, Jonathan Moss, and Gerry Stoker. 2018. The Good Politician: 
Folk Theories, Political Interaction and the Rise of Anti-Politics. Cambridge: Cambridge University Press.

Clements, Ben. 2018. British Public Opinion on Foreign and Defence Policy: 1945-2017. London: Routledge.

Colley, Linda. 2009. Britons: Forging the Nation, 1707-1837. New Haven, CT: Yale University Press.

Colley, Thomas. 2019. Always at War: British Public Narratives of War. Ann Arbor: University of Michigan Press.

Cormac, Rory. 2018. Disrupt and Deny: Spies, Special Forces, and the Secret Pursuit of British Foreign Policy. Oxford: Oxford University Press.

Cormac, Rory, and Richard Aldrich. 2018. "Covert Action Is Theatre - And the Curtain Isn't Coming Down Yet.” OUP Blog. https://blog.oup.com/2018/05/covert-action-secrecysecurity/.

Copeland, Paul, and Nathaniel Copsey. 2017. "Rethinking Britain and the European Union: Politicians, the Media and Public Opinion Reconsidered." Journal of Common Market Studies 55 (4): 709-26

Craig, Campbell, and Sergey Radchenko. 2008. The Atomic Bomb and the Origins of the Cold War. New Haven: Yale University Press.

Croft, Stuart. 2001a. "Introduction.” In Britain and Defence, 1945-2000: A Policy ReEvaluation, ed. Stuart Croft, Andrew Dorman, Wyn Rees, and Matthew Uttley, 1-8. London: Pearson Education Limited.

-. 2001b. "Britain's Nuclear Weapons Discourse." In Britain and Defence 1945-2000: A Policy 
Re-Evaluation, ed. Stuart Croft, Andrew Dorman, Wyn Rees, and Matthew Uttley. 6987. London: Pearson Education Limited.

-. 2012. Securitizing Islam: Identity and the Search for Security. Cambridge: Cambridge University Press.

Crouzet, François. 2004. 'L'Entente cordiale: Réalités et mythes d'un siècle de relations franco-britanniques.” Études Anglaises 57 (3): 310-20.

Curtis, Mark. 1995. The Ambiguities of Power: British Foreign Policy since 1945. London: Zed Books.

-. 2003. Web of Deceit: Britain's Real Role in the World. London: Random House.

Daddow, Oliver. 2004. Britain and Europe since 1945: Historiographical Perspectives on Integration. Manchester: Manchester University Press.

-. 2006. "Euroscepticism and the Culture of the Discipline of History." Review of International Studies 32 (2): 309-28.

-. 2011. New Labour and the European Union: Blair and Brown's Logic of History. Manchester: Manchester University.

-. 2015a. "Constructing a 'Great' Role for Britain in an Age of Austerity: Interpreting Coalition Foreign Policy, 2010-2015." International Relations 29, (3): 303-18.

-. 2015b. "Interpreting the Outsider Tradition in British European Policy Speeches from Thatcher to Cameron." Journal of Common Market Studies 53 (1): 71-88.

-. 2018. "Brexit and British Exceptionalism: The Impossible Challenge for Remainers." LSE Brexit, 10 April. http://blogs.lse.ac.uk/brexit/2018/04/10/brexit-and-britishexceptionalism-the-impossible-challenge-for-remainers/. 
-. 2019. "GlobalBritain ${ }^{\mathrm{TM}}$ : The Discursive Construction of Britain's Post-Brexit World Role." Global Affairs 5: 5-22.

Daddow, Oliver, and Jamie Gaskarth. 2011. "Introduction: Blair, Brown and New Labour's Foreign Policy, 1997-2010." In British Foreign Policy: The New Labour Years, ed. Oliver Daddow and Jamie Gaskarth, 1-21. London: Springer.

Daddow, Oliver, Christopher Gifford, and Ben Wellings. 2019. "The Battle of Bruges: Margaret Thatcher, the Foreign Office and the Unravelling of British European Policy." Political Research Exchange 1 (1): OnlineFirst, doi:10.1080/2474736X.2019.1643681.

Dalby, Simon. 2008. "Warrior Geopolitics: Gladiator, Black Hawk Down and The Kingdom of Heaven.” Political Geography 27 (4): 439-55.

Danchev, Alex. 1993. Oliver Franks: Founding Father. New York: Clarendon Press.

-. 1998. On Specialness. London: Macmillan.

Darwin, John. 1991. The End of the British Empire: The Historical Debate. Oxford: Basil Blackwell.

-. 2009. The Empire Project: The Rise and Fall of the British World-System, 1830-1970. Cambridge: Cambridge University Press.

Gun, Katharine. 5 March 2020. "Britain's Secret State and the Need for Whistle-Blowing." Declassified UK, 5 March. http://declassifieduk.org.

Deighton, Anne. 1990. "Missing the Boat: Britain and Europe, 1945-61." Contemporary British History 3 (3): 15-17.

-. 2003. "The Labour Party, Public Opinion and the 'Second Try' in 1967." In Harold Wilson 
and European Integration: Britain's Second Application to Join the EEC, ed. Oliver Daddow, 49-51. London: Frank Cass Publishers.

-. 2013. "Ernest Bevin." In Mental Maps in the Early Cold War Era, 1945-1968, ed. Ralph Levering. London: Palgrave Macmillan.

Dell, Edmund. 1995. The Schuman Plan and the British Abdication of Leadership in Europe. Oxford: Clarendon Press.

Dillon, G.M. 1989. The Falklands, Politics and War. London: Macmillan.

Dobson, Alan. P 1995. Anglo-American Relations in the Twentieth Century: Of Friendship, Conflict and the Rise and Decline of Superpowers. London: Routledge.

Dobson, Alan, and Steve Marsh, eds. 2017. Churchill and the Anglo-American Special Relationship. London: Routledge.

Dockrill, Saki. 2002. Britain's Retreat from East of Suez: The Choice between Europe and the World? London: Palgrave Macmillan.

Dorman, Andrew. 2001. "Crises and Reviews in British Defence Policy." In Britain and Defence, 1945-2000: A Policy Re-Evaluation, ed. Stuart Croft, Andrew Dorman, Wyn Rees, and Matthew Uttley, 9-28. London: Routledge.

Doty, Roxanne Lynn. 1996a. Imperial Encounters: The Politics of Representation in NorthSouth Relations Minneapolis: University of Minnesota Press.

-. 1996b. "Sovereignty and the Nation: Constructing the Boundaries of National Identity." In State Sovereignty as Social Construct, ed. T.J. Biersteker and Cynthia Weber, 121-47. Cambridge: Cambridge University Press.

Dumbrell, John. 2006. A Special Relationship: Anglo-American Relations from the Cold War to Iraq. 2nd ed. London: Macmillan. 
Dunne, Tim. 2004. "'When the Shooting Starts': Atlanticism in British Security Strategy." International Affairs 80 (5): 893-909.

Dyson, Stephen Benedict. 2009. The Blair Identity: Leadership and Foreign Policy. Manchester: Manchester University Press.

Eaton, George. 2018. “How the Right's Brexit Dream Died,” New Statesman, 28 November. https://www.newstatesman.com/politics/uk/2018/11/how-right-s-brexit-dream-died.

Economist. 1999. "British Irony: A Quiet Joke at Your Expense." 16 December. https://www.economist.com/christmas-specials/1999/12/16/a-quiet-joke-at-your-expense.

Edgerton, David. 2005. Warfare State: Britain 1920-1970. Cambridge: Cambridge University Press.

-. 2018a. "The Idea of Deep Continuity in British History Is Absurd: We've Always Been in Flux." Guardian, 18 November. Retrieved on 18 November from https://www.theguardian.com/commentisfree/2018/nov/18/brexit-delusional-conmenbritain-never-never-land-eu.

-. 2018b. The Rise and Fall of the British Nation: A Twentieth-Century History. London: Allen Lane.

Edmunds, Timothy. 2014. "Complexity, Strategy and the National Interest." International Affairs 90 (3): 525-39.

Edmunds, Timothy, Jamie Gaskarth, and Robin Porter. 2014. British Foreign Policy and the National Interest: Identity, Strategy and Security. Basingstoke: Palgrave Macmillan Ellison, James. 2007. “Britain and Europe.” In A Companion to Contemporary Britain 19392000, ed. Paul Addison and Harriet Jones, 517-38. Oxford: Blackwell Publishing. Ejdus, Filip. 2020. Crisis and Ontological Insecurity Serbia's Anxiety over Kosovo’s Secession. 
London: Palgrave Macmillan.

English, Richard, and Michael Kenny. 2000. “Decline or Declinism?” In Rethinking British Decline, ed. Richard English and Michael Kenny, 279-300. Basingstoke: Macmillan.

Femenia, Nora. 1996. National Identity in Times of Crises: the scripts of the FalklandsMalvinas War. New York: Nova Science Publishers.

Fichtner, Jan. 2017. “Perpetual Decline or Persistent Dominance? Uncovering Anglo-America's True Structural Power in Global Finance.” Review of International Studies 43 (1): 3-28.

Flyvbjerg, Bent. 2006. "Five Misunderstandings about Case Studies.” Qualitative Inquiry 12 (2): 219-45.

Foster, Kevin. 1997. "To Serve and Protect: Textualizing the Falklands Conflict." Cultural Studies 11 (2): 235-52.

Fox, Jon and Cynthia Miller-Idriss. 2008. “Everyday nationhood.” Ethnicities, 8(4): 536-563.

Fox, William TR. 1980. "The Super-Powers Then and Now." International Journal 35 (3): $417-36$.

Franks, Oliver. 1954. "Britain and the Tide of World Affairs, Reith Lecture No 1." http://downloads.bbc.co.uk/rmhttp/radio4/transcripts/1954_reith1.pdf.

Freedman, Lawrence. 1999. The Politics of British Defence. Hampshire: Macmillan Press.

Freedman, Lawrence, and Michael Clarke, eds. 1991. Britain in the World. Cambridge: Cambridge University Press.

Funnell, Lisa, and Klaus Dodds. 2017. Geographies, Genders and Geopolitics of James Bond. London: Palgrave Macmillan.

Gallagher, John, and Ronald Robinson. 1953. “The Imperialism of Free Trade.” Economic History Review 6 (1): 1-15. 
Gamble, Andrew. 2000. “Theories and Explanations of British Decline.” In Rethinking British Decline, ed. Richard English and Michael Kenny. New York: St Martin's Press.

-. 2003. Between Europe and America: The Future of British Politics, Basingstoke: Palgrave Macmillan.

Gaskarth, Jamie. 2011. “Identity and New Labour’s Strategic Foreign Policy Thinking.” In British Foreign Policy: The New Labour Years, ed. Oliver Daddow and Jaime Gaskarth, 84-9. Basingstoke: Palgrave Macmillan.

-. 2013. British Foreign Policy: Crises, Conflicts and Future Challenges. Cambridge: Polity.

-. 2014. "The National Interest and Britain's Role in the World." In British Foreign Policy and the National Interest: Identity, Strategy and Security, ed. Timothy Edmunds, Jamie Gaskarth, and Robin Porter, 42-65. Basingstoke: Palgrave Macmillan.

---. 2016. "Intervention, Domestic Contestation, and Britain's National Role Conceptions," in Domestic Role Contestation, Foreign Policy and International Relations, ed. Christian Cantir and Juliet Kaarbo, 105-121. London Routledge.

Gaston, Sophie. 2019. “The Impact of Returning UKIP Voters on Conservative Foreign Policy." British Foreign Policy Group blog. 5 November. https://bfpg.co.uk/2019/11/ukip-homecoming-foreign-policy/.

Gaston, Sophie, and Sacha Hilhorst. 2018. At Home in One's Past: Nostalgia as a Cultural and Political Force in Britain, France and Germany. London: Demos.

Gibbins, Justin. 2014. Britain, Europe and National Identity: Self and Other in International Relations. London: Palgrave Macmillan.

Gilroy, Paul. 2004. After Empire: Melancholia or Convivial Culture? London: Routledge.

Grahame, Alyssa M., and Srdjan Vucetic. 2019. "Making Identity 
Count: UK 2000." SocArXiv. https://osf.io/eyd4b/.

Green, Jeremy. 2020. The Political Economy of the Special Relationship: Anglo-American Development from the Gold Standard to the Financial Crisis. Princeton, NJ: Princeton University Press.

Grimmer, Justin, and Brandon Stewart. 2013. "Text as Data: The Promise and Pitfalls of Automatic Content Analysis Methods for Political Texts." Political Analysis 21 (3): $267-$ 97.

Grocott, Chris, and Jo Grady. 2014. "Naked Abroad': The Continuing Imperialism of Free Trade," Capital and Class 38 (3): 541-62.

Grob-Fitzgibbon, Benjamin. 2016. Continental Drift: Britain and Europe from the End of Empire to the Rise of Euroscepticism. Cambridge: Cambridge University Press.

Go, Julian. 2011. Patterns of Empire: The British and American Empires, 1688-Present. Cambridge: Cambridge University Press.

Guzzini, Stefano. 2012. "The Framework of Analysis: Geopolitics Meets Foreign Policy Identity Crises." In The Return of Geopolitics in Europe? Social Mechanisms and Foreign Policy Identity Crises, ed. S. Guzzini, 45-74. Cambridge: Cambridge University Press.

Hadfield-Amkhan, Amelia. 2010. British Foreign Policy, National Identity and Neoclassical

Realism. London: Rowman and Littlefield.

Haglund, David G. 2019. The US “Culture Wars” and the Anglo-American Special Relationship. New York: Palgrave Macmillan. 
Hall, Ian. 2012. Dilemmas of Decline: British Intellectuals and World Politics, 1945-75.

Berkeley: University of California Press.

Hall, Stuart. January 1979. “The Great Moving Right Show.” Marxism Today, 14-20.

-. 1981. "Notes on Deconstructing 'the Popular.'” In People's History and Socialist Theory, ed. Raphael Samuel, 227-40. London: Routledge.

-. 1996a. "Gramsci's Relevance for the Study of Race and Ethnicity." In Stuart Hall: Critical Dialogues in Cultural Studies, ed. David Morley and Kuan-Hsing Chen, 411-40. London: Routledge.

-. 1996b. "The Question of Cultural Identity." in Modernity: An Introduction to Modern Societies. eds. Stuart Hall, David Held, Don Hubert, and Kenneth Thompson, 595-634. Oxford: Blackwell.

-. 1996c. "The West and the Rest: Discourse and Power." In Modernity: An Introduction to Modern Societies, ed. Stuart Hall, David Held, Don Hubert, and Kenneth Thompson, 184-227. Cambridge: Blackwell.

--. 2000. "Reflections on British Decline: An Interview." In Rethinking British Decline, ed. Richard English and Michael Kenny. 104-116. Basingstoke: Macmillan.

Hansen, L. 2006. Security as Practice: Discourse Analysis and the Bosnian War. London: Routledge.

Harris, Peter. 2015. “America's other Guantánamo: British Foreign Policy and the US Base on Diego Garcia." Political Quarterly 86 (4): 507-14.

Harrison, Brian. 2009. Seeking a Role: The United Kingdom 1951-1970. Oxford: Oxford University Press. 
-. 2010. Finding A Role? The United Kingdom, 1970-1990. Oxford: Oxford University Press.

Haseler, Stephen. 2007. Sidekick: Bulldog to Lapdog: British Global Strategy from Churchill to Blair. London: ForumPress.

-. 2012. The Grand Delusion: Britain after Sixty Years of Elizabeth II. London: IB Tauris. Haugevik, Kristin. 2018. Special Relationships in World Politics: Inter-State Friendship and Diplomacy after the Second World War. London: Routledge.

Hay, Colin. 1999. "Crisis and the Structural Transformation of the State: Interrogating the Process of Change." British Journal of Politics and International Relations 1 (3): 317 44.

Hayes, Jarrod. 2016. "Identity, Authority, and the British War in Iraq." Foreign Policy Analysis $12(3): 334-5$.

Heinlein, Frank. 2002. British Government Policy and Decolonisation, 1945-63: Scrutinising the Official Mind. London: Frank Cass.

Henderson, Ailsa, Charlie Jeffery, Dan Wincott, and Richard Wyn Jones. 2017. "How Brexit Was Made in England." British Journal of Politics and International Relations 19 (4): $631-46$.

Henderson, Jo. 1996. "The Falklands: National Identity and the Experience of War." In Acts of War: The Representation of Military Conflict on the British Stage and Television since 1945, ed. Tony Howard and John Stokes, 192-203. Aldershot: Ashgate.

Henderson, Sir Nicholas. 1979.“Britain's Decline: Its Causes and Consequences.” FCO WRF 020/1 Diplomatic Report No. 129/70. Available at the Margaret Thatcher Foundation. https://www.margaretthatcher.org/archive/1979_Henderson_despatch.asp.

Hennessy, P. 1996. Muddling Through: Power, Politics and the Quality of Government in 
Postwar Britain. London: Weidenfeld and Nicolson.

Heuser, Beatrice. 1992. "Covert Action within British and American Concepts of Containment, 1948-1951.” In British Intelligence Strategy and the Cold War, 1945-1951, ed. Richard Aldrich, 65-84. London: Routledge.

-. 1998. Nuclear Mentalities? Strategies and Beliefs in Britain, France and the FRG. Basingstoke and New York: Macmillan.

Hill, Christopher. 1979. "Britain's Elusive Role in World Politics." British Journal of International Studies 5 (3): 248-59.

-. 2005. "Putting the World to Rights: The Foreign Policy Mission of Tony Blair." In The Blair Effect, 2001-5, ed. Anthony Seldon and Dennis Kavanagh, 384-409. Cambridge: Cambridge University Press.

-. 2016. "Powers of a Kind: The Anomalous Position of France and the United Kingdom in World Politics." International Affairs 92 (2): 393-414.

-. 2019. The Future of British Foreign Policy: Security and Diplomacy in a World after Brexit. London: Polity.

Hill, Christopher, and Sarah Beadle. 2014. The Art of Attraction. Soft Power and the UK's Role in the World. London: The British Academy.

Hills, Thomas, Chanuki Illushka Seresinhe, Daniel Sgroi, and Eugenio Proto. 2019. "Historical Analysis of National Subjective Wellbeing." Nature Human Behaviour, online first.

Hogan, Michael J. 1987. The Marshall Plan: America, Britain and the Reconstruction of Western Europe, 1947-1952. New York: Cambridge University Press.

Holland, Robert. 1991. The Pursuit of Greatness: Britain and the World Role, 1900-1970. London: Fontana. 
Holland, Jack. 2013. "Foreign Policy and Political Possibility.” European Journal of International Relations 19 (1): 49-68.

-. 2020. Selling War and Peace: Syria and the Anglosphere. Cambridge: Cambridge University Press.

Honeyman, Victoria. 2007. Richard Crossman: A Reforming Radical of the Labour Party. London: IB Tauris.

Hopf, Ted. 2002. The Social Construction of International Politics. Ithaca: Cornell University Press.

-. 2010. "The Logic of Habit in International Relations." European Journal of International Relations 16 (4): 539-61.

-. 2012. Reconstructing the Cold War: The Early Years, 1945-1958. Ithaca, NY: Cornell University Press.

-. 2013. "Common-Sense Constructivism and Hegemony in World Politics." International Organization 67 (2): 317-54.

Hopf, Ted, and Bentley B. Allan, eds. 2016. Making Identity Count: Building a National Identity Database. Oxford: Oxford University Press.

Hozic, Aida, and and Jacqui True, eds. 2016. Scandalous Economics: Gender and the Politics of Financial Crises. Oxford: Oxford University Press.

Hughes, R. Gerald, and Thomas Robb. 2013. "Kissinger and the Diplomacy of Coercive Linkage in the 'Special Relationship' between the United States and Great Britain, 196977.” Diplomatic History 37 (4): 861-905

Humphreys, Adam R. C. 2015. "From National Interest to Global Reform: Patterns of 
Reasoning in British Foreign Policy Discourse." British Journal of Politics and International Relations 17 (4): 568 - 84.

Hyam, Ronald. 2007. Britain's Declining Empire: The Road to Decolonisation, 1918-1968. Cambridge: Cambridge University Press.

Ingram, Edward. 1997. "The Wonderland of the Political Scientist.” International Security 22 (1): 53-63.

Jackson, Ashley. 2007. "Empire and Beyond: The Pursuit of Overseas National Interests in the Late Twentieth Century,” English Historical Review 122 (499): 1350-66.

Jepperson, Ronald. L., Alexander Wendt, and Peter J. Katzenstein. 1996. "Norms, Identity, and Culture in National Security." In The Culture of National Security: Norms and Identity in World Politics, ed. Peter J. Katzenstein, 33-75. New York: Columbia University Press. Jessop, Bob. 2017. "The Organic Crisis of the British State: Putting Brexit in Its Place.” Globalizations 14 (1): 133-41.

Jones, Matthew. 2018. "War and British Identity: A Study of Mass Observers' Perceptions of the Use of British Military Force since 1982.” PhD diss., Keele University.

Johnson, Rob. 2019. “UK Defence Policy: The 'New Canada' and 'International by Design.” In The United Kingdom's Defence After Brexit: Britain's Alliances, Coalitions, and Partnerships, ed. Rob Johnson and Janne Haaland Matlary, 33-57. London: Routledge. Kampfner, John. 2003. Blair's Wars. London: Simon and Schuster.

Kenny, Michael. 2014. The Politics of English Nationhood. Oxford: Oxford University Press. -. 2017. "Back to the Populist Future? Understanding Nostalgia in Contemporary Ideological Discourse.” Journal of Political Ideologies 22 (3): 256-73.

Kenny, Michael, and Nick Pearce. 2018. Shadows of Empire: The Anglosphere in British 
Politics. Cambridge: Polity.

Kertzer Joshua D., and Thomas Zeitzoff. 2017. “A Bottom-Up Theory of Public Opinion about Foreign Policy.” American Journal of Political Science 61 (3): 543-58.

Keynes, John Maynard. 1945. "Our Overseas Financial Prospects, 13 August 1945.” https://srdjanvucetic.files.wordpress.com/2018/09/keynes1945.pdf.

Kinnvall, Catarina, Ian Manners, and Jennifer Mitzen. 2018. "Ontological (in)security in the European Union.” European Security 27 (3): 249-65.

Klotz, Audie. 2008. "Case Selection." In Qualitative Methods in International Relations, ed. Audie Klotz and Deepa Prakash, 43-58. London: Palgrave.

Kolko, Joyce, and Gabriel Kolko. 1972. The Limits of Power: The World and United States Foreign Policy, 1945-1954. New York: Harper and Row.

Koschut, Simon, Todd H. Hall, Reinhard Wolf, Ty Solomon, Emma Hutchison, and Roland Bleiker. 2017. "Discourse and Emotions in International Relations." International Studies Review 19 (3): 481-508.

Kumar, Krishan. 2003. The Making of English National Identity. Cambridge: Cambridge University.

Kurki, Milja. 2008. Causation in International Relations: Reclaiming Causal Analysis. Cambridge: Cambridge University Press.

Larsen, Henrik. 1997. Foreign Policy and Discourse Analysis: France, Britain and Europe. London: Routledge.

Lawrence, Felicity, Rob Evans, David Pegg, Caelainn Barr and Pamela Duncan. 2019. "How the Right's Radical Thinktanks Reshaped the Conservative Party." Guardian, 29 November. 
https://www.theguardian.com/politics/2019/nov/29/rightwing-thinktank-conservative-borisjohnson-brexit-atlas-network.

Lawson, George. 2012. "The Eternal Divide? History and International Relations.” European Journal of International Relations 18 (3): 203-26.

Lee, Sabine. 1996. "Staying in the Game: Harold Macmillan and Britain's World Role.” In Harold Macmillan and Britain's World Role, ed. Richard Aldous and Sabine Lee, 123-48. London: Palgrave Macmillan.

Legrand, T. 2020. "Transgovernmental Anglosphere Security Networks: the Constitutive Reduction of a Shared Identity." In The Anglosphere: Continuity, Dissonance and Location, ed. Ben Wellings and Andrew Mycock. Oxford: Oxford University Press.

Leira, Halvard, and Benjamin de Carvalho. 2016. "Construction Time Again: History in Constructivist IR Scholarship.” European Review of International Studies 3 (3): 99-111.

LeMahieu, D.L. 1988. A Culture for Democracy: Mass Communication and the Cultivated Mind in Britain between the Wars. Oxford: Clarendon Press.

Lester, Nick. 2018. “A Fifth of British Troops Are Too Unfit to Fight, Warns Former Armed Forces Chief." Daily Express, 25 February, https://www.express.co.uk/news/uk/923677/British-Army-former-Armed-Forces-chiefwarns-fifth-troops-too-unfit-action.

Little, Richard. 2008. "History, Theory and Methodological Pluralism in the English School." In Theorizing International Society: English School Methods, ed. Cornelia Navari, 78103. Basingstoke: Macmillan.

Louis, W. Roger. 2006. Ends of British Imperialism: The Scramble for Empire, Suez and 
Decolonization. London: I.B. Tauris.

Louis W. Roger, and Ronald Robinson. 1994. “The Imperialism of Decolonization.” Journal of Imperial and Commonwealth History 22 (3): 462-511.

--. 2004. "Britain and the Middle East after 1945." In Diplomacy in the Middle East the International Relations of Regional and Outside Powers, ed. L. Carl Brown, 21-58. London: I. B. Tauris.

Ludlow, N. Piers. 2015. "Safeguarding British Identity or Betraying It? The Role of British 'Tradition' in the Parliamentary Great Debate on EC Membership, October 1971." Journal of Common Market Studies 53 (1): 18-34.

Mabon, Simon, Mark Garnett, and Robert Smith. 2017. British Foreign Policy Since 1945. London: Routledge.

MacDonald, Alistair. 2019. "Sources of Soft Power,” British Council Report. https://www.britishcouncil.org/sites/default/files/sources-soft-power-report-perceptionssuccess.pdf

Macleod, Alex. 1997. “Great Britain: Still Searching for Status?” In Role Quests in the PostCold War Era: Foreign Policies in Transition, ed. Philippe G. Le Prestre, 161-86. Montreal and Kingston: McGill-Queen’s University Press.

Mangold, Peter. 2001. Success and Failure in British Foreign Policy: Evaluating the Record, 1900-2000. London: Palgrave.

Marcussen, Martin, Thomas Risse, Daniela Engelmann-Martin, Hans Joachim Knopf, and Klaus Roscher. 1999."Constructing Europe? The Evolution of French, British and German Nation State Identities." Journal of European Public Policy 6 (4): 614-33. 
Marsh, Steve. 2019. "Anglo-American relations and the past present: insights into an (ongoing) mythologisation of a special relationship." Journal of Transatlantic Studies 17(3): 310-340. Mattern, Janice Bially. 2005. Ordering International Politics: Identity, Crisis and Representational Force. London: Routledge.

MccGwire, Michael. 2006. "Comfort Blanket or Weapon of War: What Is Trident For?," International Affairs 82 (4): 639-50.

McClintock, Anne. 1995. Imperial Leather: Race, Gender, and Sexuality in the Colonial Contest. New York: Routledge.

McCormack, Theresa. 2011. “From ‘Ethical Foreign Policy’ to National Security Strategy: Exporting Domestic Incoherence.” In British Foreign Policy: The New Labour Years, ed. Oliver Daddow and Jamie Gaskarth, 103-22. New York: Springer.

McCourt, David M. 2011. "Rethinking Britain's Role in the World for a New Decade: The Limits of Discursive Therapy and the Promise of Field Theory." British Journal of Politics and International Relations 13 (2): 145-64.

-. 2013. "Embracing Humanitarian Intervention: Atlanticism and the UK Interventions in Bosnia and Kosovo.” British Journal of Politics and International Relations 15 (2): 24662.

-. 2014a. Britain and World Power since 1945: Constructing a Nation's Role in International Politics. Ann Arbor: University of Michigan Press.

-. 2014b. "Has Britain Found Its Role?" Survival 56 (2): 159-78.

Martill, Benjamin, and Monika Sus. 2014. "Post-Brexit EU/UK Security Cooperation: NATO, CDSP+, or 'French Connection'?” British Journal of Politics and International Relations 20 (4): 846-63. 
Mckenzie, Francine. 2006. 'In the National Interest: Dominions' Support for Britain and the Commonwealth after the Second World War." Journal of Imperial and Commonwealth History 34 (4): 553-76.

Milward, Alan. 2003. The Rise and Fall of a National Strategy, 1945-1963. Vol 1: The UK and the European Community. London: Frank Cass.

Mitts, Tamar. 2019. "Terrorism and the Rise of Right-wing Content in Israeli Books." International Organization 73 (1): 203-24.

Mitzen, Jennifer. 2006. "Ontological Security in World Politics: State Identity and the Security Dilemma." European Journal of International Relations 12, (3): 341-70.

Mondon, Aurélien, and Aaron Winter. 2018. "Whiteness, Populism and the Racialisation of the Working Class in the United Kingdom and the United States.” Identities 26 (5): 510-28.

Morris, Justin. 2011. "How Great Is Britain? Power, Responsibility and Britain's Future Global Role." British Journal of Politics and International Relations 13 (3): 326-47.

Mumford, Densua, and Torsten J. Selck. 2010. "New Labour's Ethical Dimension: Statistical Trends in Tony Blair's Foreign Policy Speeches.” British Journal of Politics and International Relations 12: 295-312.

Murphy, Philip. 2012. "Britain as a Global Power in the Twentieth Century," in Britain's Experience of Empire in the Twentieth Century, ed. Andrew Thompson, 33-75. Oxford: Oxford University Press.

Murray, Donette. 2000. Kennedy, Macmillan and Nuclear Weapons. Basingstoke: Macmillan. Murray, Michelle K. 2019. The Struggle for Recognition in International Relations, Status, Revisionism, and Rising Powers. Oxford: Oxford University Press.

NBC News. 1963. "President Kennedy Proclaims Winston Churchill First Honorary Citizen of 
US.” NBC News Archive, https://archives.nbclearn.com/portal/site/k-

$\underline{12 / \text { browse/?cuecard }=64695}$.

Namusoke, Eva. 2016. “A Divided Family: Race, the Commonwealth and Brexit.” Round

Table 105 (5): 463-76.

Navari, Cornelia. 2008. "What the Classical English School Was Trying to Explain, and Why Its Members Were Not Interested in Causal Explanation.” In Theorizing International Society: English School Methods, ed. Cornelia Navari, 39-57. Basingstoke: Macmillan.

Neuendorf, Kimberly A. 2004. "Content Analysis: A Contrast and Complement to Discourse Analysis." Qualitative Methods: Newsletter of the American Political Science Association Organized Section on Qualitative Methods 2 (1): 33-6.

Noyes, Dorothy, and Tobias Wille. 2020. Framing paper for the conference "Exemplarity: Performance, Influence, and Friction in Political Innovation." The Mershon Center for International Security Studies, Columbus, Ohio, 27-29 February.

Oliver, Tim. 2018. Understanding Brexit: A Concise Introduction. Bristol: Policy Press.

Onslow, Sue. 1997. Backbench Debate within the Conservative Party and Its Influence on British Foreign Policy, 1948-57. New York: St Martin's Press.

O’Toole, Fintan. 2018. Heroic Failure: Brexit and the Politics of Pain. London: Head of Zeus. Oppermann, Kai, Ryan K. Beasley, and Juliet Kaarbo. 2019. “British Foreign Policy after Brexit: Losing Europe and Finding a Role.” International Relations 1-24, https://doi.org/10.1177/0047117819864421.

Paul, Kathleen. 1997. Whitewashing Britain: Race and Citizenship in the Postwar Era. Ithaca, 
NY: Cornell University Press.

Parmar, Inderjeet. 2005. 'I'm Proud of the British Empire’: Why Tony Blair Backs George W. Bush.” Political Quarterly 76 (2): 218-31.

Parr, Helen. 2006. "Britain, America, East of Suez and the EEC: Finding a Role in British Foreign Policy, 1964-67." Contemporary British History 20 (3): 403-21.

-. 2014. "National Interest and the Falklands War." In British Foreign Policy and the National Interest, ed. Timothy Edmunds, Jamie Gaskarth, Robin Porter, 66-82. London: Palgrave Macmillan.

Peden, George C. 2012. "Suez and Britain's Decline as a World Power." Historical Journal 55 (4): 1073-96.

Peyrefitte, Alain. 1994. C'était de Gaulle. Paris: Editions de Fallois-Fayard.

Pierre, Andrew. 1972. Nuclear Politics. Oxford: Oxford University Press.

Perkins, Frank. 2003. “A Year in Japan, Post-Hiroshima: Cameron Highlanders as Occupation Force.” BBC WW2 People's War Archive. https://www.bbc.co.uk/history/ww2peopleswar/stories/57/a1143857.shtml.

Porter, Patrick. 2010. "Why Britain Doesn’t Do Grand Strategy." RUSI Journal 155 (4): 6-12.

-. 2018. Blunder: Britain's War in Iraq. Oxford: Oxford University Press.

Pythian, Mark. 2007. The Labour Party, War and International Relations. London: Routledge. Raab, Dominic. 2012. "Unleashing the British Underdog.” Centre for Policy Studies. https://www.cps.org.uk/research/unleashing-the-british-underdog/.

Ralph, Jason. 2011. “A Difficult Relationship: Britain's ‘Doctrine of International Community' and America's 'War on Terror.”' In British Foreign Policy: The New Labour Years, ed. Oliver Daddow and Jaime Gaskarth, 123-38. Basingstoke: Palgrave Macmillan. 
Rasmi, Adam. 2019. "Only 1\% of Brits Cared Much about the EU before the 2016 Brexit Vote." Quartz, 10 October. https://qz.com/1725402/only-1-percent-of-brits-cared-aboutthe-eu-before-brexit/.

Rees, Wyn. 2001. “Britain's Contribution to Global Order.” In Britain and Defence, 1945-2000: A Policy Re-evaluation, ed. Stuart Croft, Andrew Dorman, Wyn Rees and Matthew Uttley, 29-48. Harlow: Pearson.

Reifler, Jason, Harold D. Clarke, Thomas J. Scotto, Paul Whiteley, David Sanders, and Marianne C Stewart. 2014. "Prudence, Principle and Minimal Heuristics: British Public Opinion Toward the Use of Military Force in Afghanistan and Libya." British Journal of Politics and International Relations 16 (1): 28-55.

Reynolds, David. 2000. Britannia Overruled: British Policy and World Power in the Twentieth Century. 2nd ed. London: Routledge.

-. 2017. "Britain, the Two World Wars, and the Problem of Narrative." Historical Journal 60 (1): 197-231.

Richardson, Louise. 1992. “Avoiding and Incurring Losses: Decision-Making in the Suez Crisis.” International Journal 47 (2): 370-401.

Rifkind, Malcolm. 2010. “The Future of UK Foreign Policy: Sir Malcolm Rifkind.” In IDEAS reports - special reports, ed. Nicholas Kitchen. LSE Research Online, http://eprints.1se.ac.uk/43554/1/The\%20future\%20of\%20UK\%20foreign\%20policy_Sir\% 20Malcolm\%20Rifkind(lsero).pdf.

Reuters. 2019. "Britain to Become 'Second Rate' in the World after Brexit: EU's Tusk." 13 November, https://www.reuters.com/article/us-britain-eu-tusk/britain-to-become-secondrate-in-the-world-after-brexit-eus-tusk-idUSKBN1XN2MG. 
Ritchie, Nick. 2012. A Nuclear Weapons-Free World? Britain, Trident and the Challenges Ahead. Basingstoke: Palgrave Macmillan.

Robbins, Keith. 1998. Great Britain: Identities, Institutions and the Idea of Britishness. Harlow: Longmans.

Robinson, Ronald and John Gallagher, with Alice Denny. 1961. Africa and the Victorians: The Official Mind of Imperialism. London: Macmillan.

Rogers, Paul. 2006. "Big Boats and Bigger Skimmers: Determining Britain's Role in the Long War." International Affairs 82 (4): 651-65.

Røren, Pål and Paul Beaumont. 2019. "Grading greatness: evaluating the status performance of the BRICS," Third World Quarterly 40 (3): 429-450.

Rossdale, Chris. 2015. "Enclosing Critique: The Limits of Ontological Security," International Political Sociology 9 (3): 369-386.

Rubin, Bret. 2010. "The Rise and Fall of British Fascism: Sir Oswald Mosley and the British Union of Fascists," Intersections 11 (2): 323-80.

Runnymede Trust and the TIDE Project, University of Liverpool. 2019. Teaching Migration, Belonging and Empire in Secondary Schools (Report).

https://www.runnymedetrust.org/uploads/images/TIDE\%20\&\%20\%20Runnymede\%20Teaching \%20Migration\%20report\%204.7.19.pdf, July 3.

Sanders, David, and David Patrick Houghton. 2017. Losing an Empire, Finding a Role: British Foreign Policy since 1945. New York: Macmillan International Higher Education.

Sanders, David, and Geoffrey Edwards. 1994. "Consensus and Diversity in Elite Opinion: The Views of the British Foreign Policy Elite in the early 1990s." Political Studies 42: 41340. 
Saunders, Robert A., and Vlad Strukov. 2018. Popular Geopolitics Plotting an Evolving Interdiscipline. London: Routledge.

Saunders, Robert. 2018. Yes to Europe! The 1975 Referendum and Seventies Britain. Cambridge: Cambridge University Press.

-. 2019. "The Myth of Brexit as Imperial Nostalgia." Prospect Magazine, 7 January. https://www.prospectmagazine.co.uk/world/the-myth-of-brexit-as-imperial-nostalgia.

Savage, Mike. 2010. Identities and Social Change in Britain since 1940: The Politics of Method. Oxford: Oxford University Press.

Schaad, Martin. 1998. "Plan G-A 'Counterblast'? British Policy towards the Messina Countries, 1956." Contemporary European History 7 (1): 39-60.

Shonfield, Andrew. 1958. British Economic Policy Since the War. London: Penguin

Schenk, Catherine. 2010. The Decline of Sterling: Managing the Retreat of an International Currency, 1945-1992. Cambridge: Cambridge University Press.

Schnapper, Pauline. 2011. British Political Parties and National Identity: A Changing Discourse 1997-2010. Cambridge: Cambridge Scholars Publishing.

Schneer, Jonathan. 1984. "Hopes Deferred or Shattered: The British Labour Left and the Third Force Movement, 1945-49." Journal of Modern History 56 (2): 198-226.

Schofield, Camilla. 2013. Enoch Powell and the Making of Postcolonial Britain. Cambridge: Cambridge University Press.

-. 2019. "Brexit and Other Special Relationship." In Embers of Empire in Brexit Britain, ed. Stuart Ward and Astrid Rasch, 87-100. London: Bloomsbury. Self, Robert. 2010. British Foreign and Defence Policy since 1945: Challenges and Dilemmas in a Changing World. Basingstoke: Palgrave Macmillan. 
Sharma, Mihir. "Britain's a Small Country." Bloomberg Opinion, 16 January 2019, https://www.bloomberg.com/opinion/articles/2019-01-16/post-brexit-britain-should-getused-to-being-a-small-country.

Shaw, Tony. 1996. Eden, Suez and the Mass Media: Propaganda and Persuasion during the Suez Crisis. London: I.B. Tauris.

Shilliam, Robbie. 2018. Race and the Undeserving Poor: From Abolition to Brexit. Newcastle upon Tyne: Agenda Publishing.

Shifrinson, Joshua R. 2018. Rising Titans, Falling Giants: How Great Powers Exploit Power Shifts. Ithaca, NY: Cornell University Press.

Simms, Brendan. 2016. Britain's Europe: A Thousand Years of Conflict and Cooperation. London: Penguin UK.

-. 2001. Unfinest Hour: Britain and the Destruction of Bosnia. London: Allen Lane.

Skey, Michael. 2009. National Belonging and Everyday Life. Basingstoke: Palgrave.

-. 2010. “'A Sense of Where You Belong in the World': National Belonging, Ontological

Security and the Status of the Ethnic Majority in England.” Nations and Nationalism 16 (4):

$715-733$.

Slobodian, Quinn. 2018. “Against the Neoliberalism Taboo.” Focaal blog, 12 January. https://www.focaalblog.com/2018/01/12/quinn-slobodian-against-the-neoliberalismtaboo/.

Smith, Julie. 2017. The UK's Journeys into and out of the EU: Destinations Unknown. London: Routledge.

Smith, Evan, and Steven Gray. 2016. "Brexit, Imperial Nostalgia and the 'White Man's 
World." History and Policy. http://www.historyandpolicy.org/opinionarticles/articles/brexit-imperial-nostalgia-and-the-white-mans-world.

Smith, Matthew. 2020. "How unique are British attitudes to empire?" YouGov International, 11 March. https://yougov.co.uk/topics/international/articles-reports/2020/03/11/how-uniqueare-british-attitudes-empire.

Smith, Simon C., ed. 2008. Reassessing Suez 1956: New Perspectives on the Crisis and Its Aftermath. Aldershot: Ashgate.

Spelling, Alex. 2009. "Edward Heath and Anglo-American Relations 1970-1974: A Reappraisal." Diplomacy and Statecraft 20 (4): 638-58.

Spiering, Menno. 2014. A Cultural History of British Euroscepticism. Basingstoke: Palgrave.

Sprout, Harold, and Margaret Sprout. 1963. "Retreat from World Power: Processes and Consequences of Readjustment." World Politics 15, (30): 655-88.

Steele, Brent J. 2008. Ontological Security in International Relations: Self-identity and the IR State. London: Routledge.

Stockwell, A.J. 2008. "Suez 1956 and the Moral Disarmament of the British Empire.” In Reassessing Suez 1956: New Perspectives on the Crisis and Its Aftermath, ed. Simon C. Smith, 227-38. Aldershot: Ashgate Publishing ltd.

Stockwell, Sarah. 2018. The British End of the British Empire. Cambridge: Cambridge University Press.

Strange Susan. 1971. Sterling and British Policy. Oxford: Oxford University Press.

Strong, James. 2017. Public Opinion, Legitimacy and Tony Blair's War in Iraq. London: Routledge.

-. 2018. "Using Role Theory to Analyse British Military Intervention in the Syrian Civil War 
during David Cameron's Premiership.” British Politics 12 (1): 42-62.

Subotić, Jelena. 2015. "Narrative, Ontological Security, and Foreign Policy Change." Foreign Policy Analysis 12 (4): 610-27.

Subotić, Jelena, and Brent J. Steele. 2018. "Moral Injury in International Relations." Journal of Global Security Studies 3 (4): 387-401.

Suzuki, Shogo. 2018. ““World Is Marvelling at Japan!': Japanese Strategies to Cope with 'Decline.'" Paper presented at the 59th Annual Convention of the International Studies Association in San Francisco, California, 4-7 April.

Taylor, Peter J. 2016 [1991]. Britain and the Cold War: 1945 as Geopolitical Transition. London: Bloomsbury Academic.

Tate, Simon. 2012. A Special Relationship? British Foreign Policy in the Era of American Hegemony. Manchester: University of Manchester Press.

Thackeray, David and Richard Toye, 2019. "Debating Empire 2.0." In Embers of Empire in Brexit Britain, ed. Stuart Ward and Astrid Rasch, 15-24. London: Bloomsbury.

Thatcher, Margaret. 3 1982. "Speech to Conservative Rally at Cheltenham." https://www.margaretthatcher.org/document/104989.

Thomas, Martin, and Richard Toye. 2017. Arguing about Empire: Imperial Rhetoric in Britain and France, 1882-1956. Oxford: Oxford University Press.

Thomas, Martin. 2014. Fight or Flight? Britain, France, and their Roads from Empire, Oxford: Oxford University Press.

Todd, John. 2016. The UK's Relationship with Europe: Struggling over Sovereignty. London: Routledge.

Tomlinson, Jim. 2017. Managing the Economy, Managing the People: Narratives of Economic 
Life in Britain from Beveridge to Brexit. Oxford: Oxford University Press.

Tooze, Adam. 2017. 'Logics of Brexit and the Perils of 'Owning the Economy': Engaging with Watkins and Davies.” Personal blog post, 7 March.

https://adamtooze.com/2017/03/07/logics-brexit-perils-owning-economy-engagingwatkins-davies/.

Toye, Richard. 2013. "Words of Change: The Rhetoric of Commonwealth, Common Market, and Cold War, 1961-3." In The Wind of Change: Harold Macmillan and British Decolonization, ed. Larry Butler and Sarah Stockwell, 140-58. Basingstoke: Palgrave Macmillan.

Towle, Philip. 2009. Going to War: British Debates from Wilberforce to Blair. Basingstoke: Palgrave Macmillan.

Travis, Alan. 2011. "Thatcher Went behind Cabinet's Back with Trident Purchase." Guardian, 30 December. https://www.theguardian.com/uk/2011/dec/30/thatcher-cabinet-opposedtrident-purchase.

Tugendhat, Christopher, and William Wallace. 1988. Options for British Foreign Policy in the 1990s. London: Routledge/RIIA.

Uttley, Matthew, Benedict Wilkinson, and Armida van Rij. 2019. “A Power for the Future? Global Britain and the Future Character of Conflict.” International Affairs 95 (4): 80116.

Valluvan, Sivamohan. 2019. The Clamour of Nationalism: Race and Nation in Twenty-FirstCentury Britain. Manchester: Manchester University Press.

Vernon, James. 2017. Modern Britain, 1750 to the Present. Cambridge: Cambridge University Press.

Verrier, Anthony. 1983. Through the Looking Glass: British Foreign Policy in an Age of 
Illusions. London: Jonathan Cape.

Vickers, Rhiannon. 2003. The Labour Party and the World. Vol. 1: The Evolution of Labour's Foreign Policy, 1900-51. Manchester: Manchester University Press.

-. 2011. The Labour Party and the World. Vol 2: The Evolution of Labour's Foreign Policy, 1900-51. Manchester: Manchester University Press.

Vieira, Marco A. 2018. “(Re-)imagining the 'Self' of Ontological Security: The Case of Brazil's Ambivalent Postcolonial Subjectivity." Millennium 46 (2): 142-64.

Vucetic, Srdjan. 2004. "Identity is a Joking Matter: Intergroup Humor in Bosnia," Spaces of Identity 3 (2): 1-28.

Vucetic, Srdjan. 2011a. "Genealogy as a Research Tool in International Relations." Review of International Studies 37 (3): 1295-312.

Vucetic, Srdjan. 2011b. The Anglosphere: A Genealogy of a Racialized Identity in International Relations. Stanford, CA: Stanford University Press.

Vucetic, Srdjan. 2011c. “A Racialized Peace? How Britain and the US Made Their Relationship Special." Foreign Policy Analysis 7 (3): 403-21.

Vucetic, Srdjan. 2011d. "What Is So American about the American Empire?" International Politics 48 (2-3): 251-70.

Vucetic, Srdjan. 2016a. "British National Identity and the Anglo-American Special Relationship.” Journal of Transatlantic Studies 14 (3): 272-92.

Vucetic, Srdjan. 2016b. "Making It Count Beyond IR.” In Making Identity Count: Towards a National Identity Database, ed. Ted Hopf and Bentley Allan, 201-18. Oxford: University of Oxford Press. 
Vucetic, Srdjan. 2017a. "Identity and Foreign Policy." Oxford Research Encyclopedia of

Politics. https://oxfordre.com/politics/view/10.1093/acrefore/9780190228637.001.0001/acrefore$\underline{9780190228637-\mathrm{e}-435}$

Vucetic, Srdjan. 2017b. “The Global in Canada.” International Journal 72 (2): 217-29.

Vucetic, Srdjan. 2017c. “A Nation of Feminist Arms Dealers? Canada and Military Exports," International Journal 72 (4): 503-19.

Vucetic, Srdjan. 2018. "Identity and Foreign Policy." In Oxford Bibliographies in International

Relations, ed. Patrick James, https://www.oxfordbibliographies.com/view/document/obo9780199743292/obo-9780199743292-0250.xml

Vucetic, Srdjan. 2019a. "Making Identity Count: UK 1950." SocArXiv. https://osf.io/eyd4b/. Vucetic, Srdjan. 2019b. "Making Identity Count: UK 1960.” SocArXiv. https://osf.io/eyd4b/. Vucetic, Srdjan. 2019c. "Making Identity Count: UK 1970.” SocArXiv. https://osf.io/eyd4b/. Vucetic, Srdjan. 2020a. “America in “British” History Textbooks.” In Culture Matters: AngloAmerican Relations and the Intangibles of "Specialness," ed. Steve Marsh and Robert M.

Hendershot, 41-65. Manchester: Manchester University Press.

Vucetic, Srdjan. 2020b. "The Anglosphere beyond Security.” In The Anglosphere: Continuity, Dissonance and Location, ed. Ben Wellings and Andrew Mycock, 77-91. Oxford: Oxford University Press.

Vucetic, Srdjan, and David Orr. 2019. "Making Identity Count: UK 1980.” SocArXiv. https://osf.io/eyd4b/.

Vucetic, Srdjan, and Kristen Olver. 2019. "Making Identity Count: UK 1990.” SocArXiv. https://osf.io/eyd4b/.

Vucetic, Srdjan, and T. Hopf. 2020. "Everyday Nationalism and Making Identity Count." 
Nationalities Papers. https://www.cambridge.org/core/journals/nationalitiespapers/firstview.

Wallace, William. 1970. "World Status without Tears.” In The Age of Affluence: 1951-1964, ed. Vernon Bogdanor and Robert Skidelsky, 53-68. New York: Macmillan.

-. 1975. The Foreign Policy Process in Britain. London: Royal Institute of International Affairs/Allen Unwin.

-. 1990. The Transformation of Western Europe. London: Royal Institute of International Affairs/Pinter.

-. 1991. "Foreign Policy and National Identity in the United Kingdom." International Affairs 67 (1): $65-80$.

-. 2005a. "The Collapse of British Foreign Policy." International Affairs 81 (1): 53-68.

-. 2005b. Europe or the Anglosphere? British foreign policy between Atlanticism and European Integration. London: John Stuart Mill Institute.

Walton, Calder. 2013. Empire of Secrets: British Intelligence, the Cold War and the Twilight of Empire. London: HarperPress.

Waltz, Kenneth Neal. 1967. Foreign Policy and Democratic Politics: The American and British Experience. New York: Little, Brown and Company.

Ward, Paul. 2004. Britishness since 1870. London: Routledge.

Ward, Steven. 2019. "Logics of Stratified Identity Management in World Politics." International Theory 11 (2): 211-38.

Ward, Stuart, and Astrid Rasch. 2019. "Introduction: Greater Britain, Global Britain.” In Embers of Empire in Brexit Britain, ed. Ward and Rasch, 1-14. London: Bloomsbury.

Wearing, David. 2014. "Critical Perspectives on the Concept of the 'National Interest': 
American Imperialism, British Foreign Policy and the Middle East." In British Foreign Policy and the National Interest, ed. Timothy Edmunds, Jamie Gaskarth and Robin Porter, 102-19. Basingstoke: Palgrave Macmillan.

-. 2018. AngloArabia: Why Gulf Wealth Matters to Britain. London: Polity.

Webster, Wendy. 2005. Englishness and Empire, 1939-1965. Oxford: Oxford University Press. Wellings, Ben. 2019. English Nationalism, Brexit and the Anglosphere. Manchester: Manchester University Press.

Wellings, Ben, and Andrew Mycock, eds. 2020. The Anglosphere: Continuity, Dissonance and Location. Oxford: Oxford University Press.

Wendt, Alexander. 1999. Social Theory of International Politics. Cambridge: Cambridge University Press.

Whitmeyer, Joseph. 2002. "Elites and Popular Nationalism.” British Journal of Sociology 53 (3): $321-41$.

Whittaker, Nick. 2017. "The Island Race: Ontological Security and Critical Geopolitics in British Parliamentary Discourse." Geopolitics 23 (4): 1-32.

Whitman, Richard G. 2019. "The UK's European Diplomatic Strategy for Brexit and Beyond." International Affairs 95 (2): 383-404.

Wickham-Jones, Mark. 2000. “Labour's Trajectory in Foreign Affairs: The Moral Crusade of a Pivotal Power?” In New Labour’s Foreign Policy: A New Moral Crusade?, ed. Richard Little and Mark Wickham-Jones, 3-32, Manchester: Manchester University Press.

Willcox, David. R. 2005. Propaganda, the Press and the Conflict. The Gulf War and Kosovo. London: Routledge.

Williams, Paul. 2005. British Foreign Policy under New Labour, 1997-2005. Basingstoke: 
Palgrave Macmillan.

Young, Hugo. 1998. This Blessed Plot: Britain and Europe from Churchill to Blair. London: Macmillan.

Young, John W. 1989. “'The Parting of Ways'? Britain, the Messina Conference and the Spaak Committee, June-December 1955." In British Foreign Policy, 1945-56, ed. Michael Dockrill and John W. Young, 197-224. Basingstoke: Macmillan.

Zarakol, Ayşe. 2011. After Defeat, How the East Learned to Live with the West. Cambridge: Cambridge University Press.

-. 2017. "States and Ontological Security: A Historical Rethinking." Cooperation and Conflict $52(1): 48-68$. 